\title{
Antilisterial Potential of Lactic Acid Bacteria in Eliminating Listeria monocytogenes in Host and Ready-to-Eat Food Application
}

\author{
Phui-Chyng Yap ${ }^{1}$, Nor-Aziyah MatRahim ${ }^{1,2}$, Sazaly AbuBakar ${ }^{1}$ and Hai Yen Lee ${ }^{1, *(D)}$ \\ 1 Tropical Infectious Diseases Research and Education Centre (TIDREC), Level 2, \\ High Impact Research Building, Universiti Malaya, Kuala Lumpur 50603, Malaysia; \\ phuichyng.yap@gmail.com (P.-C.Y.); aziyahrahim@yahoo.com (N.-A.M.); sazaly@um.edu.my (S.A.) \\ 2 Virology Unit, Institute for Medical Research, National Institutes of Health (NIH) Complex, \\ Jalan Setia Murni U13/52, Seksyen U13, Setia Alam, Shah Alam 40170, Malaysia \\ * Correspondence: leehaiyen@um.edu.my; Tel.: +60-03-79676670
}

check for updates

Citation: Yap, P.-C.; MatRahim, N.-A.; AbuBakar, S.; Lee, H.Y Antilisterial Potential of Lactic Acid Bacteria in Eliminating Listeria monocytogenes in Host and Ready-to-Eat Food Application. Microbiol. Res. 2021, 12, 234-257. https://doi.org/10.3390/ microbiolres 12010017

Academic Editor:

Beniamino T. Cenci-Goga

Received: 26 January 2021

Accepted: 20 February 2021

Published: 18 March 2021

Publisher's Note: MDPI stays neutral with regard to jurisdictional claims in published maps and institutional affiliations.

Copyright: (c) 2021 by the authors. Licensee MDPI, Basel, Switzerland. This article is an open access article distributed under the terms and conditions of the Creative Commons Attribution (CC BY) license (https:// creativecommons.org/licenses/by/ $4.0 /)$.

\begin{abstract}
Listeriosis is a severe food borne disease with a mortality rate of up to $30 \%$ caused by pathogenic Listeria monocytogenes via the production of several virulence factors including listeriolysin O (LLO), transcriptional activator (PrfA), actin (Act), internalin (Int), etc. It is a foodborne disease predominantly causing infections through consumption of contaminated food and is often associated with ready-to-eat food (RTE) and dairy products. Common medication for listeriosis such as antibiotics might cause an eagle effect and antibiotic resistance if it is overused. Therefore, exploration of the use of lactic acid bacteria (LAB) with probiotic characteristics and multiple antimicrobial properties is increasingly getting attention for their capability to treat listeriosis, vaccine development, and hurdle technologies. The antilisterial gene, a gene coding to produce antimicrobial peptide (AMP), one of the inhibitory substances found in $\mathrm{LAB}$, is one of the potential key factors in listeriosis treatment, coupled with the vast array of functions and strategies; this review summarizes the various strategies by LAB against $L$. monocytogenes and the prospect in development of a 'generally regarded as safe' LAB for treatment of listeriosis.
\end{abstract}

Keywords: infectious diseases; listeriosis; antilisterial; lactic acid bacteria; vaccine development; immunity; hurdle technology

\section{Introduction}

Listeria monocytogenes is well known for its tolerance of low $\mathrm{pH}$ (4.5), high salt conditions $(10 \% \mathrm{NaCl})$, low temperature $\left(-1{ }^{\circ} \mathrm{C}\right)$, and acid tolerance response (ATR) [1-4], which contribute to its common contamination of food. Listeria contamination is commonly reported in dairy products, ready-to-cook fish, and meat products such as smoked salmon and sausage, therefore, they are considered as high-risk foods. Despite the conditions of food storage and processing, such as high salt and low temperature, L. monocytogenes can survive and multiply to an infectious dose because of its halotolerance and psychrotolerance ability [2,3,5-8]. A susceptible population, e.g., immunocompromised and immunosuppressed individuals, is at a higher risk and could develop a more severe Listeria infection after consuming Listeria-contaminated food [1,9]. Although L. monocytogenes can be inactivated by pasteurization or heating procedure in food processing, there is a possibility of recontamination or cross-contamination at the post-food-processing line such as during preparation, cooking, and storing $[1,2,8,9]$. Consumption of food contaminated with L. monocytogenes at an infectious level could lead to the development of a life-threatening foodborne disease, known as listeriosis. Listeriosis is developed through the production of several virulence factors, including listeriolysin O (LLO), transcriptional activator (PrfA), actin (Act), internalin (Int), etc. [10,11]. Table 1 summarizes the proteins involved in pathogenesis of Listeria. Upon 
entry of L. monocytogenes into host cells, PrfA is highly activated and leads to the synthesis and secretion of virulence factors [11-13]. The virulence of L. monocytogenes is associated with pathogenic characteristics that support and promote intracellular survival by cell entry, escape from host vacuole, replication, and spreading to adjacent cells. The survival and multiplication of L. monocytogenes in host cell cytosol enable it to damage the host cell, which is crucial in pathogenesis, instead of killing it [14-16]. The major virulence factor, LLO, is a crucial protein to allow the escape of L. monocytogenes from the host vacuole and grow intracellularly in the targeted cell. Thus, LLO-deficient L. monocytogenes are not pathogenic and poorly immunogenic even at high concentrations because of the lack of the gene that encodes the LLO toxin (hly gene). The absence of LLO will prevent L. monocytogenes from escaping the vacuole and therefore, it will not be able to infect other cells [15].

Listeriosis has a high mortality rate (about 20-30\%) compared with other pathogenic microorganisms such as Campylobacter species and Salmonella species [5,17]. Listeria infection causes high hospitalization rates (91\%) and large outbreaks of human illness worldwide, with approximately 500 deaths reported annually in the United States [5]. The food previously reported to cause Listeria outbreaks (from 2010 to 2015) in the U.S. includes cold cuts, raw vegetables, ice-creams, and ready-to-eat foods [2,6]. The European Food Safety Authority (EFSA) and the European Centre for Disease Prevention and Control has reported that listeriosis was the most frequent cause of death related to the foodborne outbreak in Europe from 2008 to 2012 [5]. It has been reported that listeriosis is considered one of the etiological factors in pregnancy infection and fetal infection in India, especially during the perinatal period $[8,18,19]$. Listeriosis can have devastating effects in immunocompromised individuals. The elderly (60 years and above), pregnant women, HIV / AIDS patients, and chronic lymphocytic leukemia patients have 2.6- [20], 20- [21], 300- [21], and 1000-fold [22] greater risk of acquiring listeriosis, respectively, compared with the healthy population. However, the prevalence of listeriosis in healthy individuals is low, with an estimated rate of 0.7 cases per 100,000 people compared with immunosuppressed individuals with 100 cases per 100,000 people [3].

Because listeriosis is a type of bacterial infection, it is often treated with antibiotics. Antibiotics such as ampicillin or penicillin combined with aminoglycosides such as gentamicin [1] and trimethoprim, or in combination with sulfamethoxazole [3] are common antibiotics of choice in the treatment of listeriosis. However, antibiotics ampicillin and penicillin are only bacteriostatically effective against L. monocytogenes and not suitable for $\beta$-lactam allergy individuals [1]. Although trimethoprim-sulfamethoxazole is bactericidal, it is not suitable for sulfur allergy individuals, and carries the risk of kernicterus and teratogenic effects such as neural tube defects [9]. The use of antibiotics in food products has been banned in Europe because the overutilization of antibiotics can contribute to the emergence and dissemination of antimicrobial resistance among bacterial pathogens or directly to humans and animals, via horizontal gene transfer, increasingly becoming a threat to global public health $[23,24]$. To reduce the risk of listeriosis, the food industry implemented Good Hygiene Practices, Good Manufacturing Practices, and Hazard Analysis Critical Control Points, ensuring the hygiene and safety of food production. Some commercial microbial agents against L. monocytogenes that have been approved by the U.S. Food and Drug Administration (U.S. FDA) as food-grade preservatives include PhageGuard Listex ${ }^{\mathrm{TM}}$, LMP 102, and Nisaplin ${ }^{\circledR}$ [25], which can be applied in food processing. 
Table 1. Proteins involved in Listeria pathogenesis [10-13,16,26,27].

\begin{tabular}{|c|c|}
\hline Protein & Function \\
\hline Positive regulatory factor A (prfA) & Expresses the secretion of other virulence factors \\
\hline Listeria adhesion protein (LAP) & $\begin{array}{l}\text { Facilitates the interaction between L. monocytogenes and host cell receptor, e.g., E-cadherin and } \\
\text { mesenchymal epithelial transition factor (c-Met) found in adherens junction of } \\
\text { epithelial tissue }\end{array}$ \\
\hline $\begin{array}{l}\text { Invasion associated protein (IAP), } \\
\text { e.g., p60 }\end{array}$ & Adheres and invades host cells \\
\hline $\begin{array}{l}\text { Pore-forming hemolysin, e.g., } \\
\text { Listeriolysin O (LLO) }\end{array}$ & $\begin{array}{l}\text { Binds to cholesterol on host cell membranes for pore formation leading to rapid } \mathrm{Ca}^{2+} \text { influx } \\
\text { and } \mathrm{K}^{+} \text {efflux, triggering histone modification that modulates gene expression, damage of cell } \\
\text { membrane, induce mitochondrial fragmentation, and alteration of immune cell function that } \\
\text { enhances bacterial internalization }\end{array}$ \\
\hline $\begin{array}{l}\text { Hydrolytic enzymes, e.g., } \\
\text { phosphatidylinositol-specific } \\
\text { phospholipase (PI-PLC), } \\
\text { phosphatidylcholine-specific } \\
\text { phospholipase (PC-PLC) }\end{array}$ & Disrupts host cell vacuolar membrane and escapes to the cytoplasm \\
\hline $\begin{array}{l}\text { Surface actin assembly-inducing } \\
\text { protein, e.g., Actin A (ActA) }\end{array}$ & $\begin{array}{l}\text { Promotes movement of L. monocytogenes towards host cell surface and invades neighbor cells } \\
\text { through disruption by LLO and p60 }\end{array}$ \\
\hline Internalin A (Inl A) & Adheres to E-cadherin and mediates L. monocytogenes internalization into the host cell \\
\hline Internalin B (Inl B) & $\begin{array}{l}\text { Adheres to c-Met causing phosphorylation of Met and promotes L. monocytogenes entry to } \\
\text { host cell }\end{array}$ \\
\hline
\end{tabular}

Novel approaches have been widely explored in the employment of lactic acid bacteria (LAB) in food application for food safety, quality improvement, and shelf-life extension, by utilizing nutrient or attachment sites on gastrointestinal tract (GIT) competition, or through the production of antimicrobial compounds such as organic acids, ethanol, hydrogen peroxide, bacteriocin, etc. [28-32]. LAB are also found to promote health benefits such as enhancing gastrointestinal barrier function and serum cholesterol reduction [28,29] with the advantage that LAB have shown no activity or toxicity toward eukaryotic cells and are sensitive to digestive proteases, which ensures no negative impact or only little effect on gut microbiota $[28,32,33]$. Because of the safety recognition of LAB such as Generally Recognized As Safe (GRAS) by the U.S. FDA and Qualified Presumption of Safety status by the EFSA [24,34-36], the application of LAB as natural preservatives in the food industry is preferable and acceptable by consumers and because several detrimental effects have been reported on the use of chemical preservatives [28-30], degradation of food nutrients, and the expansion of antibiotic resistance by bacteria $[29,37,38]$. The capability of antimicrobial substances produced by LAB during food processing, as a biocontrol, has directed food manufacturers' attention to LAB's application in food processing. Several studies have demonstrated the antilisterial effects of LAB bacteriocins or enzymes in food products such as fresh and cooked meats, vacuum packaged meat, and dairy products $[29,31,33,37]$, suggesting that LAB or their metabolites are potential agents to restrain Listeria activity. LAB bacteriocin can be used as a bioactive compound in food preservation and food safety, either solely or in combination with plant extracts such as essential oils or phytochemicals, or other treatments such as heating, irradiation, high pressure, etc., therefore act as part of hurdle technology [28,30]. The mechanism of action of LAB against L. monocytogenes is detailed in the following section.

\section{Mechanisms of Lactic Acid Bacteria (LAB) against L. monocytogenes}

2.1. Production of Inhibitory Substances

2.1.1. Organic Acids

LAB produce a wide range of microbial inhibitory compounds, including organic acids as a major product, ethanol, diacetyl, carbon dioxide, hydrogen peroxide, and bacte- 
riocin. The main antimicrobial compound responsible for LAB's activity against pathogens is production of organic acids, mainly lactic acid and acetic acid, which have been proved to show a strong inhibitory effect against pathogenic bacteria $[39,40]$. Organic acids are known to acidify intracellular $\mathrm{pH}$, generating a selective barrier by inducing an unfavorable microenvironment for nonacidophiles. This leads to interference with the membrane potential and disruption of the cytoplasmic membrane, reduces nonacidophiles' cytoplasmic $\mathrm{pH}$ and alters cell metabolism, including inhibition of protein synthesis and nutrient absorption, genetic material demolition, damaging enzymes, or energy depletion due to counteraction of the microenvironment alteration, hence resulting in cell death [39,41]. However, this may not apply to L. monocytogenes [42] due to its behavior of ATR by importing and decarboxylation of glutamate and catabolism of arginine to ornithine, which involves the consumption of protons and thus an increase in intracellular $\mathrm{pH}$ that plays a critical role in Listeria virulence [43,44]. Based on Rios-Covian et al. [45], L. monocytogenes produces lactic acid as the main product under anaerobic metabolism and co-culture of L. monocytogenes anaerobically with Bifidobacterium breve, which produces lactic acid and acetic acid as by-products. Hemolytic activity of L. monocytogenes was found to be increased due to activation of LLO function in an acidic environment, which indicated that organic acid inhibitory activity is L. monocytogenes-strain dependent. On the other hand, several studies reported antilisterial activity by organic acids (not produced from the LAB) including undissociated lactic acid as the essential factor for L. monocytogenes inhibition and have proven the inhibitory effect of lactic acid against L. monocytogenes in Gouda cheese [46]; acetic acid showed a significant inhibitory effect on L. monocytogenes present in cold-smoked salmon and poultry, yet the quality and sensory properties of the food products were not adversely affected [47,48]. This suggested that the antilisterial activity of organic acids is highly dependent on Listeria strains. Short-chain fatty acids (SCFAs) such as butyrate produced by LAB in food fermentation or gut microbiota have been reported to induce epithelial cell differentiation and enhance barrier integrity, prevent adhesion of pathogenic bacteria, or indirectly inhibit the virulence gene expression at the transcriptional level, as reported in Salmonella typhimurium and L. monocytogenes by changing bacterial membrane fatty acids composition [44,49].

\subsubsection{Bacteriocin}

Bacteriocin is a ribosomally synthesized polypeptide, exerting bactericidal or bacteriostatic activity toward sensitive bacteria produced by various bacterial species, including LAB $[28,39,50,51]$. LAB bacteriocins' potential is emerging as a novel substitute for antibiotics due to its broad-spectrum or specific cytotoxicity and antagonistic activity against targeted pathogenic bacteria. Most importantly, their nature is produced by GRAS bacteria with no associated health risks $[25,34,52]$. Bacteriocin classification is complex because they can be classified according to their molecular weight, mode of action, chemical structure, etc. [29,40,53]. Class IIa bacteriocins such as pediocin PA-1 (Pediococcus acidilactici), enterocin A (Enterococcus faecium), and sakacin A (Lactobacillus sakei), which are classified based on biochemical and genetic properties, consist of a highly conserved hydrophilic $\mathrm{N}$-terminal domain with consensus motif YGNGYV (tyrosine, glycine, asparagine, glycine, tyrosine, valine), known as the pediocin box that is responsible for activity against $L$. monocytogenes $[28,50,53-55]$. Their cationic terminal interacts with anionic lipids present in the targeted bacterial cell membrane via electrostatic interaction or specific receptors such as the mannose phosphotransferase (Man-PTS) system on targeted specific bacterial species but not other populations within the same ecosystem [42], ensuring a limited spectrum of inhibition to the targeted bacterial species $[39,56]$. The electrostatic interaction and/or Man-PTS system interference led to inhibition of peptidoglycan cell wall biosynthesis of targeted bacteria and depolarization of the cellular membrane potential. The membrane permeabilization causes dissipation of proton motive force and water potential, ATP depletion, leading to cell lysis and leakage of nutrients and intracellular metabolites $[25,28,30,51]$. The electrostatic interaction's antilisterial efficiency is highly dependent on the presence of 
charged ions or net charges of bacteriocin molecules [57]. LAB bacteriocins may act through both mechanisms, cell wall inhibition and pore formation, which act as an added potential in preventing bacteriocin resistance development [28]. The antilisterial activity of LAB bacteriocins was also reported to reduce virulence gene expression or protein production. Several studies have shown bacteriocin's capability in L. monocytogenes inhibition-150 AU/mL and $300 \mathrm{AU} / \mathrm{mL}$ rhamnocin 519 derived from Lactobacillus rhamnosus CJNU 0519 decreases by $0.33 \log \mathrm{CFU} / \mathrm{mL}$ and no viable cells of L. monocytogenes detected at $3 \mathrm{~h}$ of incubation, respectively [54]; sakacin A produced by L. sakei DSMZ 6333 was shown to permeabilize Listeria cells' membrane, dissipating both transmembrane potential and transmembrane $\mathrm{pH}$ gradient, leading to the leakage of cellular materials [55]; pediocin PA-1 produced by $P$. acidilactici UL5 induced elimination of Listeria, approximately $5 \log$ reduction within $5 \mathrm{~h}$ in the ileum [56]; Lactobacillus reuteri INIA P572 produces reuterin with a strong antilisterial effect [58]; $2.5 \mathrm{mg} / \mathrm{L}$ of nisin suppressed growth of L. monocytogenes for up to eight weeks in chilled conditions, and 12,800 AU/g of enterocin reduced L. monocytogenes by $1.67 \mathrm{log}$ cycle in salami [59]. It is possible for Listeria to become immune to bacteriocins such as nisin (Class I bacteriocin) or Class IIa bacteriocin as reported via the production of the enzyme nisinase, which degrades nisin [29], altering the fatty acid composition, thickness, charge, or fluidity of its cell membrane [25,29,51], preventing the binding of nisin to lipid II; through a spontaneous bacteriocin resistant mutant outgrowth [42,60]; cross-resistance to other antimicrobial compounds $[42,51]$ or other classes of bacteriocins $[25,29]$. Besides, the presence of genes, e.g., cell wall synthesis gene $d l t A$ and penicillin-binding protein gene lmo2229 or increased expression of $\beta$-glucoside-PTS involved in mptACD gene downregulation causing the absence of Man-PTS permease has been reported as resistant against class I and class IIa bacteriocins, respectively [25,61]. Immunity proteins produced by L. monocytogenes may either bind to bacteriocin for immobilization or the Man-PTS of the listerial cell membrane as a competitive site, leading to the inability to form pores and Listeria remains intact. As a result, bacteriocins fail to exert their antilisterial function effectively despite efficient production [25].

Production of bacteriocin is inducible by gene expression, which requires the presence of an auto-inducer and is dependent on their growth phase, culture media components such as carbon and nitrogen sources, and environmental factors such as temperature, $\mathrm{pH}$, and incubation atmosphere $[30,52,57,62]$. The common commercial culture media for LAB include de Man, Rogosa and Sharpe (MRS), brain heart infusion (BHI), tryptic soy (TS), M17 media, and sodium lactate (NaLa), which support the rapid growth of LAB, yet are eminently strain-dependent. Nonetheless, high LAB bacteriocin production and activity are not inevitably based on cell yield, optimal growth, and LAB viability [52,62]. Certain LAB may produce bacteriocin during the log growth phase and stop at the stationary phase or only start producing during the stationary phase; insufficient nutrients or oversupply of nutrients can negatively affect LAB growth because excess insoluble nutrients in broth further affect the stability of bacteriocin production. Optimal growth temperature may not be similar to optimal bacteriocin production temperature because suboptimal growth temperature slows LAB growth rate and maximizes availability of essential metabolites. The $\mathrm{pH}$ of the culture media greatly affects LAB growth, cell aggregation, proteolytic degradation, protein solubility, biosynthetic gene regulation, and/or enzymatic reaction, influencing bacteriocin activity and stability; oxygen availability influences bacteriocin production, especially the facultative anaerobic nature of LAB; and agitation contributes to the introduction of an oxygen supply but could reduce bacteriocin activity due to shear effect, chemical degradation, and gene regulation [52,62]. The maximum bacteriocin production of $P$. acidilactici kp10 was obtained in M17 media (43.7 AU/g cell/h), followed by TS broth (26.70 AU/g cell/h), nutrient broth (NB) (11.21 AU/g cell/h), and MRS broth (7.46 AU/g cell/h), suggesting the rich nitrogen sources in M17 contribute to high bacteriocin production [63]. Lactobacillus curvatus, E. faecium, Lactobacillus paracasei subsp. paracasei, and Streptococcus thermophilus have grown well in MRSB and BHI $\left(>10^{8} \mathrm{CFU} / \mathrm{mL}\right)$. However, the bacteriocin production in $\mathrm{BHI}$ culture $(<70 \mathrm{AU} / \mathrm{mL})$ is much lower than 
in MRSB culture ( $>340 \mathrm{AU} / \mathrm{mL}$ ). Higher bacteriocin activity was demonstrated by LAB cultivated at $\mathrm{pH} 5.5$ in $\mathrm{BHI}$ instead of $\mathrm{pH}$ 6.2; the latter had better growth [62].

Class IIa bacteriocin is known for its active inhibition activity against $L$. monocytogenes, suggesting its production is based on antilisterial gene expression. The gene expression is often regulated by a two-component regulatory system or three-component regulatory system that includes an inducer peptide (prepeptide), transmembrane histidine protein kinase (inducer peptide receptor), and cytosolic response regulator [30,64]. Depending on the bacteriocin, the inducer peptide could be the bacteriocin itself such as nisin and brevicin $174 \mathrm{~A}$, whereas some other bacteriocins, such as lactococcal bacteriocin LsbB, regulate their expression by stabilizing RNA [30]. The inducer peptide contains an amino acid leader sequence at the $\mathrm{N}$-terminus, which serves a critical role in bacteriocin gene expression to maintain the inactive status of the inducer peptide to protect itself from the high concentration of active peptides in the host cell. The amino acid leader sequence is cleaved and removed by a proteolytic domain in transport systems such as ABC transporter or sec-dependent transporter to undergo modification by the regulatory system [64,65], thereby coordinating the translocation of inducer peptides to the transport system, which allows excretion of mature bacteriocin. The gene encoding for LAB immunity proteins or the regulation protein involved in bacteriocin production is located in a gene cluster responsible for the bacteriocin structural gene, causing the immunity protein genes to be cotranscribed with bacteriocin structural genes. Therefore, the immunity protein production is reduced with bacteriocin production, protecting itself from its bacteriocin activity $[64,66,67]$. Other than bacteriocins, other compounds produced by LAB also possesses antimicrobial properties and is summarized in Table 2.

Table 2. Mechanisms action of other antimicrobial substances produced by LAB [29,34,35].

\begin{tabular}{cll}
\hline Antimicrobial Substances & \multicolumn{1}{c}{ Source } & \multicolumn{1}{c}{ Mechanisms of Action } \\
\hline $\mathrm{CO}_{2}$ & $\begin{array}{l}\text { A by-product of } \\
\text { fermentation from } \\
\text { heterofermentative } \\
\text { LAB }\end{array}$ & $\begin{array}{l}\text { Interacts with cell membranes by reducing internal and external } \mathrm{pH} . \\
\text { Inhibit enzymatic decarboxylation by an accumulation of } \mathrm{CO}_{2}, \\
\text { creating an anaerobic environment that effectively prevents aerobic } \\
\text { microbial growth by causing dysfunction in permeability and } \\
\text { produces carbonic acid. }\end{array}$ \\
& $\begin{array}{l}\text { Metabolites } \\
\text { produced by LAB } \\
\text { in the presence } \\
\text { of oxygen }\end{array}$ & $\begin{array}{l}\text { A powerful oxidizing agent that oxidizes sulfhydryl groups and } \\
\text { destroys the bacterial enzymatic activity. } \\
\text { Causing peroxidation of membrane lipids and cell proteins, hence } \\
\text { increasing cell membrane permeability, losing components, } \\
\text { and cell death. } \\
\text { Acts as a precursor for bacterial free radicals such as superoxide } \\
\left(\mathrm{O}_{2}^{-2}\right) \text { and hydroxyl }\left(\mathrm{OH}^{-}\right) \text {radicals, which damage DNA. }\end{array}$ \\
\hline
\end{tabular}

\subsection{Competitive Exclusion}

Competitive exclusion is defined as the presence of at least one nonpathogenic bacterium that reduces the number of pathogenic bacteria, either directly or indirectly via different types of mechanisms such as competition for nutrients or receptor sites in the GIT [39]. In general, nonpathogenic bacteria and pathogenic bacteria compete against each other in a host for available nutrients, causing depletion of the nutrient supply to an opponent and cell death, hence effectively excluding the host's population. The growth rates of pathogenic bacteria and nonpathogenic bacteria present in the microenvironment are important for nutrient competition. A faster-growing bacterium leads to faster uptake of nutrients and inhibits opponents due to insufficient available nutrients in the microenvironment $[68,69]$. Pathogenic bacteria could also be excluded by nonpathogenic bacteria through the competition for adhesion receptors expressed on host cells [41]. Biofilm formation of 
bacteria through quorum sensing plays an essential role in colonization in a host, which aids in the prevention of the attachment of opponent cells $[39,40,70]$. The competition for nutrients and attachment sites was suggested to co-occur. The sequence of bacterial treatment in both competition for nutrients and attachment sites significantly affects bacterial dominance in the microenvironment. LAB have been suggested to be better than the pathogen in attachment competition. This is because certain LAB are able to modify the microenvironment to be unfavorable for L. monocytogenes survival through the production of antimicrobial substances [39,49], or to attach specifically onto host cells through the production of other molecules such as lipids or free proteins that facilitate close contact to host cells [71].

\subsubsection{Competition for Nutrients}

All microorganisms require different compositions and concentrations of nutrients for survival and growth. The metabolic activity of L. monocytogenes may not be influenced by antimicrobial substances, e.g., organic acids and bacteriocin produced by LAB, due to their acid tolerance properties and production of proteolytic enzymes. Thus, the LAB's growth rate plays a critical role in presiding in the microenvironment to compete for nutrients with L. monocytogenes. Inhibition of L. monocytogenes by Carnobacterium piscicola has been reported. This dual bacteriocin-producing strain has a higher growth rate at chilled temperatures, via nutrient competition, than bacteriocin [60]. According to Saraoui et al. [68], Lactococcus piscium was faster growing than L. monocytogenes, which may result in quicker uptake of nutrients, and this competition may involve a partial inhibition mechanism but is bacterialconcentration dependent. However, the limited nutrients present in the host cell after LAB consumption may stress L. monocytogenes for survival and replication, causing stimulation of virulence gene expression [72]. PrfA, which plays a role in activating virulence factors, is positively regulated by the stress-responsive sigma $B$ factor $\left(\sigma^{B}\right)$. Therefore, under stress conditions such as insufficient nutrients or acid or oxidative stresses, L. monocytogenes may express its virulence factors such as protein InlA and InlB or immune response to counteract the stresses. The InlA and InlB were reported to be also co-activated by both $\sigma^{\mathrm{B}}$ and $\operatorname{Prf} A$, suggesting the effectiveness of virulence gene expression under stress conditions [72,73]. Similarly, the LAB may also struggle with limited nutrients and induce bacteriocin to overcome survival stress.

\subsubsection{Niche Competition}

Adhesion of L. monocytogenes on host cells is crucial for their invasion and virulence [74,75]. For instance, heparin and heparin sulfate expressed on epithelial host cells act as the receptor for bacteria attachment such as di-glucosyl-di-acyl-glycerol/lipoteichoic acid of E. faecium and ActA of L. monocytogenes [76]. LAB surface adhesins embedded in the cell wall or anchored in the cell through lipid moiety, e.g., mucus adhesion-promoting protein) and mucus-binding protein produced by L. reuteri and Lactobacillus fermentum, potentiate their attachment to the host cell by facilitating close contact and colonization through the degradation of the extracellular matrix of cells [49]. LAB can prevent the attachment of L. monocytogenes on host cells through (i) colonization on host cells and (ii) saturation of L. monocytogenes attachment receptor.

The sequence of bacterial treatment affects the degree of L. monocytogenes attachment inhibition by LAB via different mechanisms: direct competition, displacement, and exclusion. Studies have shown that pretreatment of LAB on intestinal epithelial cells significantly reduced L. monocytogenes invasion by up to $90 \%$ [77]; pretreatment of LAB on abiotic surfaces effectively prevented the attachment of the incoming $L$. monocytogenes by reducing attachment of L. monocytogenes $2.82 \log$ and $3.81 \log$ after $24 \mathrm{~h}$ and $72 \mathrm{~h}$, respectively [69]; the simultaneous treatment of LAB and L. monocytogenes that enables direct cell-to-cell competition to the available attachment sites effectively reduced $L$. monocytogenes attachment by $4.38 \log$ and $3.22 \log$ after $24 \mathrm{~h}$ and $72 \mathrm{~h}$, respectively, with LAB concentration as low as $10^{6} \mathrm{CFU} / \mathrm{mL}$ [69]. LAB's degree of inhibition of L. monocytogenes on both abiotic surfaces and epithelial cells is highly dependent on cell concentration, cell hydrophobicity, and 
extracellular polysaccharide substances (EPS). Wang et al. [70] reported an L. rhamnosus GC mutant that produced low capsular polysaccharide, possessing a weak biofilm-forming capacity and adhesion. In the event where L. monocytogenes have occupied the attachment site, LAB inhibit L. monocytogenes invasion by inhibiting their access to the available nutrients.

Nevertheless, it is notable that L. monocytogenes invasion can occur via the production of proteolytic enzymes or immunity protein that could defend against LAB and/or LAB inhibitory compounds. Specific molecules present on the LAB surface or their metabolites act as ligands binding to L. monocytogenes attachment receptors [71,78]. As a result, L. monocytogenes receptor sites that are responsible for gastrointestinal cell attachment were altered and malfunctioned. These LAB metabolites and surface molecules involved in the adhesion and co-aggregation of L. monocytogenes that interfere with their attachment are related to bacteria specificity. According to Saraoui et al. [68], the cell-to-cell contact is vital for LAB to inhibit L. monocytogenes from exchanging information such as genetic materials through conjugation, transport of DNA, proteins, or molecules through secretion system pathway IV, which is also supported by Zilelidou et al. [72], who declared that cell contact enables bacteria to deliver toxic compounds to an antagonist in close vicinity. In contrast, Corr and co-workers [77] showed that the invasive activity of L. monocytogenes is independent of cell-to-cell contact with LAB and suggested that the inhibition of L. monocytogenes invasion was mainly due to inhibitory substances secreted by LAB, which was supported by Rios-Covian et al. [45].

\subsection{Reduction of L. monocytogenes Virulence Availability by $L A B$}

A new approach of utilizing LAB to reduce the virulence expression of pathogens has been reported in several studies via modulation of gene or protein expression through bacterial signaling mechanisms. Upadhyay et al. [79] showed that LAB, including L. reuteri, L. fermentum, Lactobacillus plantarum, and Lactococcus lactis, significantly reduced L. monocytogenes adhesion and invasion of Caco-2 cells (approximately 1.5 to $2 \log \mathrm{CFU}$ ) and downregulated most $L$. monocytogenes virulence genes, including $\operatorname{prf} A, \operatorname{plc} A, \operatorname{plc} B$, hly, act $A$, inl $A$, inlB, and iap, up to sixfold change, but the degree of reduction is LAB-strain dependent. These reduction activities are enhanced with the combination of eugenol extracted from clove oil, suggesting LAB's potential as part of hurdle technology. Another study by Winkelströter and De Martinis [80] demonstrated that bacteriocins derived from E. faecium, Leuconostoc mesenteroides, and L. sakei significantly decreased the expression of inlA from different sources of L. monocytogenes. Food-isolated L. monocytogenes reduced their adhesive and invasive properties on Caco-2 cells. Interestingly, adhesion of L. monocytogenes isolated from a food-processing environment is inversely proportional to invasion of Caco-2 cells when treated with LAB bacteriocins. This suggested that L. monocytogenes adhesion was independent of invasion of Caco-2 cells. The adhesion and invasion of L. monocytogenes on Caco-2 cells and inhibitory effect of LAB are interrelated to L. monocytogenes strain, LAB strain, and environmental conditions. According to Rios-Covian et al. [45], co-culture of Bifidobacteria with L. monocytogenes caused overexpression of the hly gene and luxS gene, which are involved in the regulation of biofilm formation. The early expression of the hly gene extracellularly causes energy dissipation and disrupts virulence efficacy, whereas the expression of the luxS gene repressed L. monocytogenes biofilm formation and weakened the adhesion of L. monocytogenes onto host cells. Similar studies were reported on the lower virulence gene expression of non-Listeria species. For instance, expression virulence genes of Salmonella enterica (SPI-1 and SPI-2), Clostridium difficile ( $t c d A$ and $t c d B$ ), and Clostridium perfringens (cpb2) were downregulated by LAB, e.g., Lactobacillus bulgaricus, L. paracasei, Lactobacillus acidophilus, and L. fermentum, instead of bacteriocin-like inhibitory substances, reducing the pathogenicity $[38,81,82]$. Nevertheless, the pathogenicity of L. monocytogenes and antagonistic effect of LAB involved several factors and regulatory mechanisms; thus, more studies are required to discover their roles in listeriosis. 


\section{Role of LAB in Host Cells against L. monocytogenes Infection}

\subsection{Protection of Gastrointestinal Tract from L. monocytogenes Invasion}

The GIT is a complex microecosystem consisting of diverse microbiota, e.g., Lactobacilli and Bifidobacteria that influence host physiology and immunological development $[74,77]$. Gut microfloras activate the host immune system to react promptly against pathogenic infection and act as antagonists to compete for essential nutrients and colonization spaces. Intestinal epithelial cells (IECs) serve as the main target site of L. monocytogenes pathogenesis associated with the capability of attachment, invasion, and resistance of host immunity [77,83]. IECs are also said to be the first-line defense mechanism against L. monocytogenes invasion, which consist of three physical barriers, namely, single-layer epithelial cells, enteric mucosal surface layer, and epithelial junction adhesion complex with glycocalyx, which consists of mucin that aids in strengthening epithelial physical barrier function and epithelial integrity against Listeria invasion $[39,84]$. The antibacterial mechanisms possessed by microfloras could be reinforced by inoculating LAB in the microenvironment to maintain intestinal microbial balance. $\mathrm{LAB}$ enhances IECs' functions, regulates intestinal immune cell responses, eliminates gastrointestinal pathogens, and prevents postinfectious inflammation or overreaction of adaptive immunity $[41,84,85]$. The protection of GIT by LAB has been consistently reported on its effectiveness in the early control of L. monocytogenes infection $[43,86]$.

Among the three physical barriers of IECs, the mucus layer is the frontline of host intestinal defense that protects IECs from pathogens' adsorption and invasion, chemical, enzymatic, mechanical, and microbial damage [41]. The primary constituent of mucus, mucin, especially mucin2 (MUC2), and other antimicrobial peptides (AMPs), e.g., Trefoil factor 3 (TFF3) and resistin-like molecule-beta are secreted by goblet cells via transcription factor Krueppel-like factor 4 (KLF4), under normal physiological conditions. Gene expression of these mucus constituents is augmented by goblet cells to replenish and conserve the integrity of the mucus layer by increasing its viscosity $[49,87,88]$ because the presence of the toxin, food components, cytokines, and microbial colonization, or flow of digesta may cause depletion of the mucus layer $[89,90]$. Mucin sulfation is a crucial process that requires galactose-3-O-sulfotransferase 2 (GAL3ST2) and carbohydrate sulfotransferase 5 (CHST5) to reinforce the protective effect of the mucus layer against pathogenic infection and inflammation in the intestine [88]. A recent study by Ren et al. [88] showed that the upregulation of $M U C 2, T F F 3, R E T N L B$ (gene encoded for resistin-like beta protein), CHST5, and GAL3ST2 genes depended on LAB species and strains, incubation time, and the presence of cytokines, e.g., tumor necrosis factor- $\alpha$ (TNF- $\alpha$ ) and interleukin-13. For instance, Lactobacillus casei and L reuteri only significantly elevated MUC2 and TFF3 genes' expression, respectively; L. rhamnosus significantly augmented MUC2 and GAL3ST2; L. fermentum expressed the TFF3 gene to peak at $24 \mathrm{~h}$. Besides, certain cell-free supernatants (CFS) of LAB were also shown to upregulate these genes' expression, illustrating that specific compounds produced by LAB may be involved in goblet cell function modulation, which is supported by Caballero-Franco et al. (2007) [91]. It is also in line with Fernandez et al. [92], who reported that lactate produced from S. thermophilus was suggested to upregulate KLF4 protein involved in goblet cell differentiation maturation, despite weak adhesion of $S$. thermophilus onto the mucus layer of HT-29 cells. Interaction of lactate and Gpr81 (G-protein-coupled receptor) in the intestine stimulates intestinal stem cells, thereby maintaining IECs' integrity [93]. Soluble protein $\mathrm{p} 40$ produced by L. rhamnosus GG induced $M U C 2$ gene expression and mucin secretion by activating epithelial growth factor receptor (EGFR) through secretion of epithelial growth factor (EGF) without promoting goblet cell differentiation and proliferation $[91,94]$ has also been reported. These results suggested LAB metabolites' potential involvement in diverse signaling cascades activation, supporting the growth and maturation of goblet cells or mucin production [93]. Goblet cell function is influenced by the presence of cytokines and mucus integrity, which both could be augmented or attenuated by LAB species and strain, e.g., $B$. breve is a mucus degrader $[88,95]$. An in vivo study has demonstrated where the addition of LAB in animal diet significantly augmented MUC2 gene expression and increased goblet cell number 
and density, and villus length of chickens [87]; the number of intraepithelial lymphocytes, CD3+ (cluster of differentiation) cells density in Peyer's patches and lamina propria of piglets [93] compared with the normal diet. It has been suggested that Nucleotide-binding and oligomerization domain (NOD) proteins, e.g., NOD1 and NOD2, are the critical receptors for LAB to stimulate goblet cells and MUC2 production because NOD1 and NOD2 ligands have been shown to upregulate $\beta-1,3-N$-acetylglucosaminyltransferase 3 (C3GnT), which is involved in mucin synthesis and increases goblet cell numbers [96,97]. Even so, pathogens may not be eliminated by the mucus layer due to their high binding affinity to glycoproteins or glycolipids of IECs [74]. L. monocytogenes encode several proteins, e.g., lmo0576 (containing a mucin-binding protein, MucBP domain) which is also found in the MUCB protein of L. reuteri [98], and internalin has binding ability onto mucin and adheres to the mucus layer of IECs [43]. However, interestingly, under anaerobic conditions and the presence of SCFA, LLO production is increased without immediately triggering LLO activity, instead of increased mucin production and thereby enhancing the IECs barrier against $L$. monocytogenes infection $[43,99]$.

The tight junction of IECs that comprise several transmembranes and adaptor proteins is a pivotal barrier in regulating paracellular permeability and preventing invasion by L. monocytogenes. Notably, the virulence factor, LAP, e.g., alcohol acetaldehyde dehydrogenase (Aad or lmo1634), is crucial for L. monocytogenes to disrupt a tight junction actively by recognizing the epithelial receptor, heat shock protein 60 (Hsp60). This interaction activates nuclear factor-kappa B (NF- $\mathrm{kB}$ ) and stimulates myosin light-chain kinase (MLCK), which mediates remodeling of epithelial junction proteins including tight junction proteins, e.g., claudin-1 and occludin, and adherens junction protein (E-cadherin). Restructuring of these proteins leads to E-cadherin exposure on epithelial apical sites, especially in villus tips, causing IECs to be susceptible to L. monocytogenes invasion by InlA into the lamina propria $[100,101]$. Activation of c-Met by InlB has also been proposed to expose E-cadherin on the apical surface either through manifestation or stimulation of hepatocyte growth factor because c-Met signaling is involved in junction assembly. However, the mechanism is not known because c-Met is also a basolateral receptor [100]. LAP-deficient L. monocytogenes significantly reduced adhesion, invasion, and transepithelial translocation properties through Caco-2 cells [102-104], and L. monocytogenes translocation through IECs is dependent on the concentration of secretory LAP and transport protein, SecA2 [102]. It has been reported that short hairpin suppression of epithelial Hsp60 [104] and E-cadherin saturation by antibody [101] significantly dampened L. monocytogenes adhesion and invasion of IECs, suggesting the importance of Hsp60 in LAP-mediated invasion and E-cadherin receptor for L. monocytogenes invasion. Other than MLCK stimulation, LAP-mediated NF- $\mathrm{KB}$ activation independent of invasion stimulates pro-inflammatory cytokines, e.g., TNF- $\alpha$ and IL-6, and induces epithelial barrier disturbance, facilitating L. monocytogenes translocation without triggering innate immune response [101]. However, LAB's potential to antagonize LAP or epithelial Hsp60 is poorly known although L. rhamnosus, L. acidophilus, and L. paracasei have been reported to carry a LAP homolog, showing neither interaction with purified Hsp60 protein nor anti-LAP antibody [103]. Instead, probiotic bioengineering is applied by developing recombinant LAB-expressing LAP without negative impact such as cytotoxic response [105]. Surprisingly, strong interaction between Hsp60 with recombinant LAB including L. paracasei expressing LAP (Lbp ${ }^{\mathrm{LAP}}$ ) [103]; L. casei expressing inlAB (Lbc ${ }^{\mathrm{InIAB}}$ ) and LAP $\left(\mathrm{Lbc}^{\mathrm{LAP}}\right)$ [105], were even stronger compared with wild-type L. monocytogenes and wild-type LAB, resulting from high plasmid copy number in the LAB recombinants [105], hence, enabling a higher reduction of L. monocytogenes adhesion, invasion, and translocation through IECs. Prolonged exposure of Caco-2 cells to recombinant LAB exhibited L. monocytogenes adhesion, invasion, and translocation inhibition $(\geq 30 \%)$, and protection of Caco-2 cells from $L$. monocytogenes cytotoxicity up to $79 \%$ after $24 \mathrm{~h}[103,105]$. Lbc ${ }^{\mathrm{LAP}}$ and $\mathrm{Lbc}^{\mathrm{Inl} \mathrm{AB}}$ were also shown to lower transepithelial/transendothelial electrical resistance) reduction by $<10 \%$ and $<15 \%$, respectively [105], suggesting LAP of recombinant LAB plays the leading role in conserving Caco-2 cells' integrity. Koo et al. [103] suggested that 
the enhancement in Caco-2 cells' integrity by Lbp ${ }^{\mathrm{LAP}}$ was due to suppression of TNF- $\alpha$ and interferon- $\gamma(\mathrm{IFN}-\gamma)$, and subsequent regulation of tight junction protein expression.

\subsection{LAB as an Immunoadjuvant in Immunomodulation of L. monocytogenes Infection}

The innate immune system plays an important role in inducing immediate defense against acute inflammation and in activating long-lasting adaptive immunity. Innate immunity is activated via the engagement of pattern recognition receptors (PRRs) such as toll-like receptors (TLRs) that are expressed on IECs' apical site or endosome, or cytosolic NOD-like receptors (NLRs) with pathogen-associated molecular patterns (PAMPs) in the majority of pathogens [49]. PRRs including TLR2, NOD1, NOD2, and NACHT, LRR and PYD domains-containing protein 3 (NALP3), e.g., cryopyrin and IL-1 $\beta$-converting enzyme, ICE-protease activating factor (IPAF) are crucial in defending against Listeria infection, which recognizes L. monocytogenes lipoproteins, lipoteichoic acid, peptidoglycan components, e.g., meso-diaminopimelic acid and muramyl dipeptide, DNA, or toxin, e.g., LLO and p60 $[85,86,106-108]$. The recognition by these PRRs of L. monocytogenes is greatly dependent on the lgt gene encoded for prolipoprotein and type of L. monocytogenes, e.g., noncytosolic L. monocytogenes (LLO-deficiency) lead to inability to secrete IL-1 $\beta$ and IL-18 [106]. Interactions of these PRRs and PAMPs activate transcriptional factors, e.g., Myeloid differentiation primary response 88 (MyD88), NF- $\mathrm{kB}$, and interferon regulatory factor 3 , and induce proinflammatory cytokines and chemokines, e.g., TNF, IL-6, IL-12, IL$1 \beta$, IL-18, and type-I IFNs, e.g., IFN- $\alpha \beta[85,86,106,107,109,110]$. Type-I IFNs are well known for their potential in antitumor and antiviral functions that cause apoptosis, autophagy, or mediate inflammation and autoimmunity. However, these IFNs possess an opposite effect against bacterial infection, including L. monocytogenes [106], suggested to downregulate immune response or enhance bacterial growth directly. IFN- $\alpha \beta$ was also reported to suppress IFN- $\gamma$ (type-II IFNs) which are produced by natural killer (NK) to activate macrophages for phagocytosis in conjunction with TNF $\alpha$ signaling or via Janus kinases, and signal transducer and activator of transcription protein (JAK-STATs) pathway $[108,109]$. Patients or mice associated with a deficiency in IFN- $\gamma$ and TNF $\alpha$ receptors and/or gene mutations are highly susceptible to L. monocytogenes infection $[108,109]$ whereas a deficiency in type-I IFN receptors and transcriptional factor IFN-regulatory factor 3 are resistant to Listeria infection $[107,109]$, suggesting that IFN $-\gamma$ and TNF $\alpha$ are essential for primary antilisterial defense. The immunomodulatory activity exerted by LAB includes the downregulation of pro-inflammatory cytokines and upregulation of anti-inflammatory cytokines; modulation of the signaling pathway, e.g., NF- $\mathrm{kB}$, mitogen-activated protein kinases (MAPK) and phosphatidylinositol 3-kinase (PI3K) [110]. An increase in the IFN- $\gamma$ RNA level was shown with the administration of Lactobacilli in mice, which stimulated the proliferation of CD4 ${ }^{+}$ T cells [111]. Antilisterial-acting IFN- $\gamma$ plays a critical role in adaptive immunity against Listeria infection by increasing the expression of costimulatory molecules and major histocompatibility complex (MHC), thus enhancing T cells [107-109]. Other than competing for adhesion sites with L. monocytogenes, EPS of LAB, e.g., polysaccharide-peptidoglycan administration by mice, has been shown to improve their survival rate from Listeria infection mainly via activation of macrophages [70]. The interplay of these active receptors and adaptor proteins is critical in triggering host immunity by producing various IL and IFN from innate cells, e.g., monocytes, macrophages, and NK cells can respond promptly, for the effective removal of L. monocytogenes in IECs.

The production of AMPs, e.g., defensin (cryptidin), lysozyme, phospholipase A2, cathelicidin, matrix metalloproteinase 7 , and regenerating islet-derived protein 3- $\gamma(\operatorname{Reg} I I I \gamma)$ from Paneth cells may be stimulated upon production of proinflammatory cytokines [89] and/or dependent on microbial stimulation including exposure to bacterial membrane proteins $[43,89,96,112]$. LAB have been demonstrated to increase Paneth cell number and/or stimulate AMPs, depending on the type of LAB strains and epithelial environment context $[89,96]$. AMPs such as $\alpha$-defensin and cathelin-related antimicrobial peptides have been demonstrated to provide effective protection to host cells against $L$. monocytogenes 
and exert a synergistic effect with macrophages to limit the secretion of LLO and subsequent intracellular proliferation of L. monocytogenes [113,114]. Cathelicidins and defensin bind to the phospholipids group of Listeria membrane, e.g., lipid II through electrostatic force can create pores, e.g., Human Neutrophil $\alpha$-defensin 2 dimer forms multimetric pores, impedes peptidoglycan formation, and alters Listeria integrity $[41,49,112,115,116]$. The release of AMPs is partially dependent on NOD2 [49,110], the molecule particularly highly expressed on Paneth cells, and thus was suggested to be crucial to regulate Paneth cells' antimicrobial activity [96,117], or initiated by TLRs [115]. Similar to the nature of L. monocytogenes, LAB as Gram-positive bacteria consist of a peptidoglycan cell wall, lipoteichoic acid, and teichoic acid, act as microbe-associated molecular patterns (MAMPs) recognized by PRRs, e.g., TLRs and NLRs to mediate immune regulation $[70,89,118]$. The interaction of several LAB peptidoglycans with NOD or TLRs was suggested to stimulate these AMPs $[96,115,116]$, particularly defensin via subsequent MAPK, NF- $\mathrm{kB}$, or Activator protein 1 (AP-1) signaling pathway [77,89]; lysozyme via Receptor-interacting serine/threonine-protein kinase 2 (RIPK2) pathway [90,116]; or RegIII $\gamma$ via TLRs/MyD88 signaling pathway to disrupt glycosidic linkage of peptidoglycan via enzymatic reaction, promoting mucosal barrier function $[115,116]$. L. helveticus membrane protein was reported to have a greater extent in human beta-densin-2 (hBD2) expression compared with cells. The membrane protein as TLR2 antagonist activates TLR2 downstream signaling, including MAPK, NF- $\mathrm{KB}$, and mainly c-Jun N-terminal kinase signaling, mediating the upregulation of hBD2 as suggested [119]. However, the exact role of NOD in AMPs' expression is poorly known because there are conflicting reports, suggesting the possibility of an additional function of NOD in Paneth cells beyond regulation of AMPs' secretion and activity $[43,48,90,115,117,120]$. AMPs perform different functions through different mechanisms in exerting an antipathogenic effect, including enzymatic or nonenzymatic reaction, or interaction with the intracellular component to inhibit DNA and protein synthesis, and protein folding [113]. In short, every AMP plays a crucial and specific role in protecting host cells from pathogenic infection [43,114-116].

Early or excessive production of proinflammatory cytokines that trigger an inflammatory response has been shown to cause a negative impact on the host, including tissue damage, intestinal disorder, and IECs or leukocytes' apoptosis that promote pathogen virulence $[49,120]$. Upon phagocytosis, the close contact of dead phagocytes or secreted apoptogenic compounds with leukocytes leads to its apoptosis independently of L. monocytogenes infection. This cytokine-induced cell apoptosis event is increased with LLOproducing L. monocytogenes with concentrations ranging from 0.4 to $4 \mathrm{nM}$ [121]. Notably, LLO potentiates the imitation of perforin to cooperate with granzyme (serine protease) stored in cytotoxic lymphocytes (CD8 ${ }^{+} \mathrm{T}$ cells), inducing autologous apoptosis instead of target cells $[15,121,122]$. A report has shown that IL-18 and TNF-related apoptosis-inducing ligand deficient mice have reduced susceptibility to L. monocytogenes infection due to less apoptosis of leukocytes and IECs, resulting in a higher number of leukocytes including macrophages, dendritic cells (DCs), and NK cells after Listeria infection compared with wild-type mice $[107,120]$. Therefore, the production of proinflammatory cytokines, e.g., TNF- $\alpha$ and IFN- $\gamma$, needs to be regulated because an adequate amount is essential for primary antilisterial defense and required for activation of $\mathrm{T}$ cells involved in adaptive immunity whereas an excessive amount can cause detrimental effects.

LAB's potential in reducing cytokine-induced apoptosis, protecting IECs from inflammation and injury, has been widely reported. For instance, L. rhamnosus GG and L. acidophilus have been demonstrated to alleviate IECs' apoptosis, e.g., TNF- $\alpha$-induced Zonula occludens-1 disruption, which plays a critical role in preserving tight junction integrity in a cell-contact-dependent manner [110,123]. LAB metabolites, e.g., soluble proteins p40 and $p 75$, potentiate the stimulation of serine-threonine kinase to induce secretion of EGF through MMP activation, transactivation, and interaction with EGFR [110,124]. The subsequent activation of anti-apoptotic PI3K-downstream substrate, serine/threonine kinase (Akt/PKB), and inhibition of proapoptotic mitogen-activated protein kinase (p38/MAP) 
promote IECs' homeostasis. Hence, minimizing IECs' apoptosis and cytokine-induced apoptosis protects host cells from injury and inflammation $[125,126]$. TLR1 and TLR6 are indispensable for the activation of TLR2 signaling by forming heterodimers and are critical for GIT immune homeostasis maintenance. Activation of TLR2/TLR1 induces pro-inflammatory cytokines as demonstrated by L. monocytogenes, whereas activation of TLR2/TLR6 induces tolerogenic cytokines, e.g., IL-10 stimulated by regulatory T (Treg) cells which was demonstrated by LAB to possess immunological tolerance to abolish intestinal inflammation [118,127]. Nevertheless, excessive TLRs signaling stimulation can cause several diseases. L. plantarum, L. casei, L. reuteri, L. acidophilus, L. rhamnosus, Lactobacillus brevis, and $S$. thermophilus and their CFS were shown to induce anti-inflammatory IL-10 production by NF-кB/AP-1 through MyD88/AP1-dependent signaling, in which TLR2 acted as the PRR. The characteristic of heat-stable, DNase, RNase, and proteinase sensitive LAB CFS suggests the potential compounds to be proteins or nucleic acids, or possibly ligands expressed on cell surfaces. Nuclease-treated L. plantarum CFS was reported to improve TLR2 activation by the degradation of nuclease-sensitive molecules. These molecules may aggregate with MAMPs, limiting their interaction with TLR2. Therefore, removal of the molecules through enzymatic treatment will improve the accessibility of TLR2 binding sites by the MAMPs, suggesting nuclease as an auxiliary to promote LAB-produced bioactive compounds in TLR2 activation $[127,128]$. Other than an attachment, EPS of L. casei Shirota and Lactobacillus delbrueckii subsp. bulgaricus modulate host immune response by preventing pro-inflammatory IL-6 and IFN- $\gamma$ production that causes inflammation [70]. Corr et al. [77] demonstrated that L. acidophilus, L. casei, and Lactobacillus salivarius have significantly reduced pro-inflammatory cytokines (IL-8) and increased the production of anti-inflammatory cytokines (IL-10), approximately threefold reduction and 1.5-fold increase, respectively. Interestingly, there was no detectable IL-8 and IL-10 production in the absence of L. monocytogenes despite LAB's presence, suggesting the importance of innate immune response activation via the recognition of PRRs with PAMPs.

Although innate immunity is crucial for early control of L. monocytogenes infection by limiting their exponential growth, the importance of adaptive immunity in the final elimination of the pathogens is also indispensable, providing effective sterilizing protection $[85,86,129]$. The innate immune response follows an adaptive immune response, mainly triggered through the interaction of cytosolic NLRs, e.g., NOD2 with PRRs [130] and stimulated by activated DCs through recognition of PAMPs to its PRRs, leading to the expression of costimulatory molecules, e.g., TNF and cytokines $[4,39,86]$. As compared with humoral immunity, cell-mediated immunity involving $\mathrm{CD}^{+}$and $\mathrm{CD} 8^{+} \mathrm{T}$ cells contributes to major protection from L. monocytogenes infection, which is activated by the degraded Listeria peptides presented on MHC class II and class I, respectively. $\mathrm{CD}^{+} \mathrm{T}$ cells have contributed substantially and effectively in mediating adaptive immunity from Listeria infection, stimulated by endogenous listerial antigen, e.g., LLO or p60 protein loaded on MHC class I molecules. $\mathrm{CD}^{+}{ }^{+} \mathrm{T}$ cells' role is relatively less well defined in defending against Listeria infection, probably in protective immunity $[86,107,129]$ due to the kinetics and magnitudes of $\mathrm{CD}^{+}{ }^{+} \mathrm{T}$ cells, accumulation of $\mathrm{CD} 4^{+}$memory $\mathrm{T}$ cells is tissue-specific and dependent on infection route [129]. CD8 ${ }^{+} \mathrm{T}$ cells possess cytoplasmic granules containing perforin and granzymes, which lyse infected cells and expose intracellular bacteria for subsequent killing by neutrophils and activated macrophages via phagocytosis $[85,86,129]$. As mentioned above, LLO may mimic perforin and cause unwanted apoptosis of uninfected cells, thereby impairing antilisterial immunity. Humoral immunity involving antibodies did not show a significant elimination in L. monocytogenes infection, although anti-LLO monoclonal antibody has been shown to neutralize LLO [86,108,129]. However, $\mathrm{B}$ cells are essential in the efficient formation of long-lasting memory $\mathrm{CD}^{+} \mathrm{T}$ cells that differentiated from cytotoxic $\mathrm{CD}^{+} \mathrm{T}$ cells together with $\mathrm{CD} 4^{+} \mathrm{T}$ cells [108], which react promptly and protect the host from subsequent exposure to Listeria infection.

Although the immunomodulation of LAB against L. monocytogenes is mainly based on activation of the innate immune response, $\mathrm{LAB}$ plays a minor role in triggering adaptive 
immunity through innate immune response, stimulating the production of cytokines from Treg cells, e.g., IL-10 to activate DCs or specifically INF- $\gamma$ and TNF- $\alpha$ from T cells that are important for complete L. monocytogenes clearance $[70,84,108,109]$. LAB, e.g., L. paracasei subsp. paracasei NTU 101 or LAB-expressing antigen have been proved to upregulate the expression of surface proteins, e.g., CD40, CD80, CD86, and MHC class II on antigenpresenting cells (APCs) via interaction with APCs' surface peptide which activates APCs or CD154 on $\mathrm{CD}^{+} \mathrm{T}$ cells, providing costimulatory signaling for $\mathrm{T}$ cells' activation, proliferation, and differentiation to trigger costimulatory molecules and cytokines' secretion, inducing an adaptive immune response $[118,125,131]$. L. paracasei subsp. paracasei NTU 101 and L. rhamnosus GG augmented DC-T cells' interaction via STATs signaling that led to an increase in B cell number $[41,109,125]$. Wells (2011) [118] suggested the antilisterial genes present in LAB, e.g., plantaricin from L. plantarum are involved in immune response to DCs in cytokines' production because deletion of genes was found in the locus responsible for plantaricin biosynthesis and secretion ( $l p \_0403$ to $l p \_0431$ ) when co-cultured with DCs [118]. Regulation of the TLR signaling pathway by LAB also mediates the differentiation of effector $T$ cells or stimulation of macrophages and DCs [70,111], e.g., (i) L. casei upregulates expression of TLR2 and mannose (CD206) on APCs [84], (ii) B. breve BbC50SN promotes expression of CD83, CD86, and HLA-DR via activation of the TLR2 signaling pathway, which is involved in DCs' maturation [70] later stimulation of adaptive immunity, suggesting the importance of TLRs in both innate and adaptive immunity. A remarkable increase in the number of effector T cells, including helper $\mathrm{CD}^{+}$and cytotoxic $\mathrm{CD} 8^{+}$, and NK cells, has been reported in several case studies in LAB consumption as probiotic supplements [70]. Nevertheless, solely enhancing the $\mathrm{CD} 4^{+}$and $\mathrm{CD} 8^{+} \mathrm{T}$ cells' levels may cause induction of inflammatory response and overstimulation of mucus; thus, their levels should be optimal [74].

\section{LAB as a Vaccine Vector against L. monocytogenes}

The potential of LLO in antitumor vaccine development is due to their features of (i) ability to live inside the host cell, which is not possessed by other CDC-producing bacteria [132], (ii) ability to provide cytosolic access for antigens in APCs by pore formation [133]. Because infection by L. monocytogenes is closely related to contaminated food products, and the bacterium is able to bypass the mucosal barrier, mucosal vaccines may offer more advantages than vaccines delivered via the parenteral delivery route and whereby it has been demonstrated to be able to induce both mucosal and systemic immune response [134]. However, antigen delivered via mucosa induces low immune responses, probably due to rapid degradation in the mucosal secretion, poor microbial adsorption, and induction of mucosal tolerance [134,135]. LAB have a long track record for safe oral consumption, and some strains possess probiotic properties. The increasing interest in using $\mathrm{LAB}$ as a live vector has heightened the development of a vector for LAB, especially for Lactobacilli with probiotic properties [136]. Perhaps synergistic effects between the immunomodulatory properties are conferred by $\mathrm{LAB}$, and the potential antigen could elicit a better immune response at lower vaccine dosage and confer more effective protection against the infection. However, different strains of LAB demonstrated differences in their activities. Some bacteria maintain homeostasis of the intestinal microbiota, and some strains induce the immune system and repress the allergic reactions. Other probiotic strains render protection against pathogenic bacteria either by competing for the colonized surface, producing inhibiting compounds against the growth of pathogens, or by inducing mucus AMP production by the mucosal epithelial cells [136]. Among the LAB, L. lactis has been highlighted as potentially the best vaccine vehicle due to its safety and sequenced complete genome [137]. The potential of L. lactis as a vector for DNA plasmid transfer for L. monocytogenes LLO expression intracellularly and extracellularly has been demonstrated. The plasmid transfer ratio in L. lactis is low, however, with the recombinant $L$. lactis expressing the mutated InIA and LLO of L. monocytogenes with observed increase in the production of the gene of interest [138]. Besides functioning as a carrier for plasmid DNA, the potential of L. lactis in the expression of various antigen 
intracellularly and extracellularly has led to the development of an inducible expression system for L. lactis. The availability of such a system enabled the intracellular expression of many antigens in L. lactis such as tetanus toxin fragment $C$ and 28-kDa immunogen from Schistosoma mansoni $[135,139]$. In the context of a vaccine for L. monocytogenes, the $L$. lactis expression system could be employed for the expression of listerial antigens for oral route delivery. A study by Jensen et al. [140] demonstrated that the production of IFN- $\gamma$ within the animal group subcutaneously inoculated with vaccine candidate containing LLO and $\mathrm{p} 60$ in replication-deficient adenovirus-based vaccine contributed toward protective immunity against Listeria infection. Because L. lactis is also reported as an effective vehicle for cytokine delivery [134], an oral vaccine for L. monocytogenes could be developed using L. lactis for expression of listerial antigens with co-expression of cytokine (i.e., IL-12, IL-2, or IL-6). This approach perhaps could lead to effective protection against the infection, possibly similar to that reported by Jensen et al. [140] or could be better. LAB have also been demonstrated to be utilized to display a single-chain antibody fragment $(\mathrm{ScFv})$ that could be used for the generation of passive immunity [141,142]. Such an approach could be developed to treat $L$. monocytogenes because it might provide a more direct and fast response. The beneficial effects, robustness, and encouraging results on LAB's capability as a delivery system are likely to play a crucial role in future vaccine development [136]. Nevertheless, some concerns remain to be addressed. Among them is the horizontal transfer of plasmid carrying antibiotic resistance marker to the environmental and host microfloras [137]. It is also important to understand the immune response in relation to the route of administration and the level of in vivo antigen production to stimulate further vaccine development using the LAB system [135].

\section{LAB/LAB Bacteriocin as Part of Hurdle Technology}

The common food preservation technologies implemented in the food industry include heat treatment, e.g., Ultra-High-Temperature, High-Temperature-Short-Time pasteurization; dehydration, e.g., smoking, freeze-drying; pickling, and salting by addition of vinegar, sugar, and salt; addition of chemical preservatives; and prevention of oxidation or oxidative rancidity by addition of antioxidants $[143,144]$. Although these food preservation techniques effectively extend the food shelf life, they may result in food quality deterioration such as loss of nutrients and sensory attributes, and adverse health effects resulting from chemical preservatives. Thus, hurdle technology has been developed to inaugurate a series of selective protection aspects to provide a hostile environment that coerces multi-stress reactions to foodborne pathogens and spoilage microorganisms [32,143-145], minimizing food deterioration while maintaining the expected organoleptic quality through the implementation of more than one barrier including existing (temperature, pressure, $\mathrm{pH}$, etc.) and novel (antimicrobial compounds and physicochemical treatment) preservation techniques [25,144]. Hurdles interfere with microbial homeostasis by affecting their physiological processes, which lead to microbial metabolic exhaustion [25].

$\mathrm{LAB} / \mathrm{LAB}$ bacteriocin is being implemented as a natural preservative in food application. Because food is the main source of listeriosis, the effectiveness of LAB/LAB bacteriocin antilisterial activity in food applications should be widely explored. The interaction between L. monocytogenes, $\mathrm{LAB} / \mathrm{LAB}$ bacteriocin, and food matrix may lead to alteration in survival or replication of $L$. monocytogenes / $\mathrm{LAB}, L$. monocytogenes virulence gene expression, or antilisterial activity functionality of LAB/LAB bacteriocin $[7,25,29,72]$. Application of bacteriocins individually in food is unlikely to ensure complete safety [57,146], for instance, $\mathrm{LAB}$ bacteriocin is degraded by the enzymatic activity of food proteolytic enzymes, thus losing LAB bacteriocin functionality [147]. Therefore, the introduction of LAB/LAB bacteriocin in hurdle technologies with other preservation techniques reduces the application and severity of physical hurdles. This lowers the risk of LAB bacteriocin resistance by undesirable microbes and maintains food quality in safety, organoleptic, and nutrition while reaching higher lethality [7]. 
Nevertheless, several factors should be considered for incorporating LAB/LAB bacteriocin as a hurdle, including their stability in terms of temperature, wide range of $\mathrm{pH}$, tonicity, adaptability in the food matrix, and concentration [32]. Thus, appropriate intensity and a proper combination of hurdles need to be established to maximize food shelf life and quality $[25,145]$. Notably, safety concern or spoilage of hurdle-treated food may arise due to post-contamination or improper storage affected by extrinsic factors such as light $[7,25,144]$.

Nisin is the only bacteriocin approved by the FDA and World Health Organization (WHO) in food application, for example, the commercially available Nisaplin ${ }^{\circledR}$ product is a good role model of LAB bacteriocin involving hurdle technology, which employs nisin $(2.5 \% w / w)$ with the combination of $\mathrm{NaCl}(77.5 \% w / w)$, protein $(12 \% w / w)$, and carbohydrates $(6 \% w / w)[25,148]$. Nisin also has been documented to improve thermal inactivation of bacteria, which reduces treatment time and degree, preserves food quality, with cost savings. The bactericidal effect of nisin against $L$. monocytogenes was found to be enhanced with the addition of $\mathrm{NaCl}$ together with vacuum packaging and is active at low $\mathrm{pH}[7,25,57,149]$, suggesting their suitability in acidic foods' applications. Nevertheless, some studies reported that nisin is slightly inactive against $L$. monocytogenes because it is not a class IIa bacteriocin and has weak antilisterial activity when applied in meat due to high $\mathrm{pH}$, interference with meat components, and uneven distribution $[29,51,60]$. Thus, the study of antilisterial bacteriocin purified from LAB is encouraged and applied in food technology and preservation to reduce listeriosis risk.

\subsection{Encapsulation of $L A B / L A B$ Bacteriocin}

Because LAB bacteriocin is a biosynthesized peptide, its structure and function are easily degraded or inactivated by the food matrix, e.g., polar and nonpolar food components, and food processing, e.g., heat or diluted below appropriate concentration resulting from migration into the food matrix [146]. Bacteriocin is incorporated in biocompatible films or nanovesicles, e.g., alginate, gelatin, starch, guar gum, xanthan gum, or liposomes, to overcome this problem, which is known as encapsulation [150-152]. Theoretically, the thin layer of encapsulant protects $\mathrm{LAB} / \mathrm{LAB}$ bacteriocin from the fluctuating and dynamic food processing, and against other microbial competitors, thus increasing their viability, stability, and distribution. Indirect contact of encapsulated LAB/LAB bacteriocin allows them to adapt to the food matrix environment by controlling their release rate $[7,150,151]$, reducing the risk of malfunction, and ensuring their antilisterial efficacy. Several studies had proven that encapsulated $\mathrm{LAB} / \mathrm{LAB}$ bacteriocin in phosphatidylcholine-liposomes $(4-250 \mu \mathrm{g} / \mathrm{mL})[153,154]$, and the combination of alginate $(2.5 \% \mathrm{w} / \mathrm{v})[152]$ and gelatin $(6.0 \%$ $w / v)$ significantly slows the growth or reduces the number of L. monocytogenes (CFU/mL) compared with free LAB/LAB bacteriocin in dairy products, e.g., milk and cheese, and meat under refrigeration for up to at least 21 days. Notably, free bacteriocin demonstrated lower antilisterial activity due to their interaction with fat globules in milk [153], and the number of L. monocytogenes was found to increase slowly from an undetectable level after a few days under refrigeration storage, which was suggested as due to resistance of $L$. monocytogenes to LAB bacteriocin [154]. However, it has been reported that free nisin has better antilisterial activity than soy lecithin-encapsulated nisin $(250 \mu \mathrm{g} / \mathrm{mL})$, possibly resulting from the inhibitory effect of lecithin on nisin through complex formation. However, the encapsulated nisin possessed bacteriostatic properties toward L. monocytogenes [155]. Martinez et al. [148] reported that both free and encapsulated nisin showed a significant reduction of L. monocytogenes in milk. Their combination exerted a more substantial antilisterial effect, hypothesizing initial action by free nisin followed by encapsulated nisin. Barbosa et al. [156] reported that the encapsulation of bacteriocin-producing L. curvatus MBSa2 slightly improved their survival in salami, in which their count was maintained at $8 \log$ $\mathrm{CFU} / \mathrm{mL}$ for 30 days compared with free cells, and encapsulated L. curvatus MBSa2 showed a better reduction of $L$. monocytogenes in salami. In encapsulation, the encapsulant properties such as polydispersity, zeta potential, size, entrapment encapsulation, and concentration are the important factors that could influence the encapsulated antimicrobial compound 
function $[153,154]$. Le et al. [152] explained that the concentration of gelatin in the capsule influenced its viscosity and the fertility of LAB antimicrobial compounds. The highest inhibitory effect $(68.69 \%)$ against L. monocytogenes was found when encapsulated in $2.5 \%$ $(w / v)$ alginate with $6.0 \%(w / v)$ gelatin L. plantarum SC01. Besides, internal factors, e.g., composition and $\mathrm{pH}$ of food products, concentration and type of LAB/LAB bacteriocin, and external factors, e.g., storage temperature and time are critical in antilisterial activity.

\subsection{Active Packaging}

Food packaging is intended to protect food from physical damage, unwanted physiological and chemical changes, environmental factors, e.g., light, dust, and pests, and ease of transportation [144,157], especially post-processed food for long-term storage. Active packaging, e.g., vacuum packaging, modified atmosphere packaging (MAP), active scavenging, or active releasing system, were developed to enhance the strength of normal packaging and is widely used for highly perishable food, including fresh produce, meat, and fish to preserve their appearance, which is easily discolored from enzymatic reaction or oxidation $[36,144,146,158,159]$. The alteration of the external food environment promotes retardation of microbial growth, e.g., $\mathrm{CO}_{2}$ (active releasing system) inhibits aerobic bacteria and reduces ethylene sensitivity, thus inactivating or slowing enzymatic reaction [144]. Slow migration of antimicrobial agents from food packaging material to the food matrix provides a consistent exposure of antimicrobial compounds to bacteria, maintaining a high concentration where required and protecting loss of antimicrobial functionality resulting from interaction with the food matrix $[146,158]$. Antimicrobial packaging by incorporating LAB bacteriocin is an alternative strategy to extend the shelf life of food products while improving LAB bacteriocin stability and antilisterial properties in the complex food environment [51]. The introduction of LAB/LAB bacteriocin in active packaging, e.g., alginate film [160], starch/halloysite nanocomposites film [159], bioactive plastic pouches [161], and edible pullulan film [162], has been widely studied and proved to be effective against L. monocytogenes in chilled food for up to a month. Antilisterial activity of LAB/LAB bacteriocin in active packaging was reported to be augmented with a combination of LAB and LAB bacteriocin in the film [160], improved with a higher concentration of bacteriocin [159], enhanced with vacuum packaging and MAP $\left(60: 40 \mathrm{~N}_{2}: \mathrm{CO}_{2}\right)$ [161], or addition of lauric arginate, an approved synthetic preservative [162]. Spraying L. piscium EU2241 and Leuconostoc gelidium EU2247 onto shrimp before vacuum packaging slowed the growth of L. monocytogenes and their count was reduced by up to $2 \log$ at $8^{\circ} \mathrm{C}$ and $20{ }^{\circ} \mathrm{C}$ [163]. Similar to encapsulant, the effectiveness of LAB/LAB bacteriocin in the film is greatly affected by the concentration of the film nanocomposites because a higher concentration of nanocomposites delayed the bacteriocin diffusion. It is also notable that the growth of $L$. monocytogenes slowly increased during storage caused by the development of bacteriocin resistance. Therefore, an amalgamation of LAB/LAB bacteriocin with encapsulation or active packaging is suggested to delay bacteriocin resistance $[148,160]$. It has also been suggested not to apply LAB cells alone because it may not ensure complete elimination of L. monocytogenes and outgrowth of LAB may cause an undesired quality of food such as acid production that may influence the sensory attributes of food [40].

\section{Conclusions and Future Perspective}

An established and balanced gut microbiota composition can greatly benefit host immunity by maintaining host homeostasis and health. Disturbances in gut microbiota and immunity interaction can ease the translocation of a pathogen to host cells and expose the host to pathogenic infection, particularly intracellular L. monocytogenes due to immune dysregulation and subsequent autoimmune disorder. Because nisin is the only approved bacteriocin launched in the market, the advanced properties of LAB, such as antilisterial gene and gastrointestinal function and GRAS status, should attract more efforts to potentiate their role as antibiotic substitution, nutrient supplements, or biopreservatives in listerial treatment and prevention or food application. The colonization of gut microbiota in the 
host is critical and greatly augmented with LAB administration, which aids in reinforcing gut barrier function to prevent invasive $L$. monocytogenes and modulate host immune response to prevent cell injury or tissue damage.

Despite the potential of LAB in competing for host colonization with L. monocytogenes and preventing their internalization from hosting cells, the mechanism of downregulation or suppression of L. monocytogenes virulence factors gene or production is poorly understood. Gene cloning of L. monocytogenes virulence factors, e.g., LLO, LAP, and p60 in $\mathrm{LAB}$ could be developed for listeriosis vaccination. L. monocytogenes virulence factors' production is triggered by environmental stress or as metabolites. In the absence of stress or limiting nutrients for metabolism, virulence factors may still exist but are hidden or under control. L. monocytogenes and LAB's metabolic study could further identify their interaction in the host cell or food matrix that provides nutrients. However, LAB's effect in L. monocytogenes defense is greatly dependent on several factors, including LAB strains and dosage, host physiological status, type of listeriosis, or in prevention including food components' environmental factors, e.g., temperature, pressure, and light exposure. In addition, avirulent Listeria spp., e.g., L. innocua should not be overlooked because the virulence factor could be transferred readily between each other. Overall, LAB present a great potential to be used for controlling and combating listeriosis through direct inactivation to immunomodulation prospects and can also be developed into a multiprong approach against $L$. monocytogenes.

Author Contributions: Conceptualization, H.Y.L. and P.-C.Y.; methodology, P.-C.Y.; writing—original draft preparation, P.-C.Y. and N.-A.M.; writing-review and editing, H.Y.L. and S.A.; funding acquisition, H.Y.L. and S.A.; supervision, H.Y.L.; project administration, H.Y.L. All authors have read and agreed to the published version of the manuscript.

Funding: This research was funded by the Ministry of Higher Education Malaysia under the Fundamental Research Grant Scheme (FRGS049-2018A), Bantuan Kecil Penyelidik Universiti Malaya (BK056-2016) and the Higher Institution Centre for Excellence (HICoE) program (Project MO002-2019).

Institutional Review Board Statement: Not applicable.

Informed Consent Statement: Not applicable.

Data Availability Statement: No new data were created or analyzed in this study. Data sharing is not applicable to this article.

Acknowledgments: We acknowledge the funding from the Ministry of Education, Malaysia for niche area research under the Higher Institution Centre of Excellence (HICoE) program (Project MO002-2019) and the Graduate Research Assistant Scholarship (GRAS) by Institute of Advanced Studies Universiti Malaya.

Conflicts of Interest: The authors declare no conflict of interest.

\section{References}

1. Allerberger, F.; Wagner, M. Listeriosis: A resurgent foodborne infection. Clin. Microbiol. Infect. 2010, 16, 16-23. [CrossRef]

2. Buchanan, R.L.; Gorris, L.G.M.; Hayman, M.M.; Jackson, T.C.; Whiting, R.C. A review of Listeria monocytogenes: An update on outbreaks, virulence, dose-response, ecology, and risk assessments. Food Control 2017, 75, 1-13. [CrossRef]

3. Marian, M.N.; Aminah, S.M.S.; Zuraini, M.I.; Son, R.; Maimunah, M.; Lee, H.Y.; Wong, W.C.; Elexson, N. MPN-PCR detection and antimicrobial resistance of Listeria monocytogenes isolated from raw and ready-to-eat foods in Malaysia. Food Control 2012, 28, 309-314. [CrossRef]

4. Zilelidou, E.A.; Skandamis, P.N. Growth, detection and virulence of Listeria monocytogenes in the presence of other microorganisms: Microbial interactions from species to strain level. Int. J. Food Microbiol. 2018, 277, 10-25. [CrossRef] [PubMed]

5. Kuan, C.H.; Goh, S.G.; Loo, Y.Y.; Chang, W.S.; Lye, Y.L.; Puspanadan, S.; Shahril, N.; Tang, J.Y.H.; Mahyudin, N.A.; Nishibuchi, M.; et al. Risk assessment of acquiring listeriosis from consumption of chicken offal in Selangor, Malaysia. Int. Food Res. J. 2015, 22, 1711-1718.

6. Zhu, Q.; Gooneratne, R.; Hussain, M.A. Listeria monocytogenes in Fresh Produce: Outbreaks, Prevalence and Contamination Levels. Foods 2017, 6, 21. [CrossRef] [PubMed]

7. Arques, J.L.; Rodriguez, E.; Langa, S.; Landete, J.M.; Medina, M. Antimicrobial Activity of Lactic Acid Bacteria in Dairy Products and Gut: Effect on Pathogens. BioMed Res. Int. 2015. [CrossRef] 
8. Jamshidi, A.; Zeinali, T. Significance and Characteristics of Listeria monocytogenes in Poultry Products. Int. J. Food Sci. 2019, 2019, 7835253. [CrossRef]

9. Lamont, R.F.; Sobel, J.; Mazaki-Tovi, S.; Kusanovic, J.P.; Vaisbuch, E.; Kim, S.K.; Uldbjerg, N.; Romero, R. Listeriosis in human pregnancy: A systematic review. J. Perinat. Med. 2011, 39, 227-236. [CrossRef]

10. McMullen, P.D.; Freitag, N.E. Listeria monocytogenes. In Molecular Medical Microbiology; Tang, Y., Sussman, M., Liu, D., Poxton, I., Schwartzman, J., Eds.; Academic Press: Cambridge, MA, USA, 2015; Volume 2, pp. 1345-1361.

11. Bhunia, A.K. Listeria monocytogenes. In Foodborne Microbial Pathogens: Mechanisms and Pathogenesis, 2nd ed.; Bhunia, A.K., Ed.; Springer: New York, NY, USA, 2018; pp. 229-248.

12. Arslan, S.; Baytur, S. Prevalence and antimicrobial resistance of Listeria species and subtyping and virulence factors of Listeria monocytogenes from retail meat. J. Food Saf. 2019, 39. [CrossRef]

13. Coelho, C.; Brown, L.; Maryam, M.; Vij, R.; Smith, D.F.Q.; Burnet, M.C.; Kyle, J.E.; Heyman, H.M.; Ramirez, J.; Prados-Rosales, R.; et al. Listeria monocytogenes virulence factors, including listeriolysin $\mathrm{O}$, are secreted in biologically active extracellular vesicles. $J$. Biol. Chem. 2019, 294, 1202-1217. [CrossRef] [PubMed]

14. Bavdek, A.; Kostanjsek, R.; Antonini, V.; Lakey, J.H.; Serra, M.D.; Gilbert, R.J.C.; Anderluh, G. pH dependence of listeriolysin O aggregation and pore-forming ability. FEBS J. 2012, 279, 126-141. [CrossRef]

15. Carrero, J.A.; Vivanco-Cid, H.; Unanue, E.R. Listeriolysin O Is Strongly Immunogenic Independently of Its Cytotoxic Activity. PLoS ONE 2012, 7. [CrossRef] [PubMed]

16. Hamon, M.A.; Ribet, D.; Stavru, F.; Cossart, P. Listeriolysin O: The Swiss army knife of Listeria. Trends Microbiol. 2012, 20, 360-368. [CrossRef] [PubMed]

17. Jeyaletchumi, P.; Tunung, R.; Margaret, S.P.; Son, R.; Farinazleen, M.G.; Cheah, Y.K. Detection of Listeria monocytogenes in foods. Int. Food Res. J. 2010, 17, 1-11.

18. Barbuddhe, S.B.; Malik, S.V.; Kumar, J.A.; Kalorey, D.R.; Chakraborty, T. Epidemiology and risk management of listeriosis in India. Int. J. Food Microbiol. 2012, 154, 113-118. [CrossRef]

19. Tirumalai, P.S. Listeriosis and Listeria monocytogenes in India. Wudpecker J. Food Tech. 2013, 1, 98-103.

20. United States Food \& Drug Administration. Get the Facts about Listeria! Available online: https://www.fda.gov/animalveterinary / animal-health-literacy/get-facts-about-listeria (accessed on 1 March 2019).

21. World Health Organization. Listeriosis. Available online: https://www.who.int/news-room/fact-sheets/detail/listeriosis (accessed on 1 March 2019).

22. Goulet, V.; Hebert, M.; Hedberg, C.; Laurent, E.; Vaillant, V.; De Valk, H.; Desenclos, J.C. Incidence of Listeriosis and Related Mortality Among Groups at Risk of Acquiring Listeriosis. Clin. Infect. Dis. 2012, 54, 652-660. [CrossRef]

23. Adeniyi, B.A.; Adetoye, A.; Ayeni, F.A. Antibacterial activities of lactic acid bacteria isolated from cow faeces against potential enteric pathogens. Afr. Health Sci. 2015, 15, 888-895. [CrossRef]

24. Álvarez-Cisneros, Y.M.; Ponce-Alquicira, E. Antibiotics Resistance in Lactic Acid Bacteria. In Antimicrobial Resistance: A Glocal Threat; Kumar, Y., Ed.; IntechOpen: London, UK, 2018; pp. 53-73.

25. Renye, J.A.; Somkuti, G. Bacteriocins of Food Grade Lactic Acid Bacteria in Hurdle Technology for Milk and Dairy Products. In Emerging Dairy Processing Technologies: Opportunities for the Dairy Industry; Datta, N., Tomasula, P.M., Eds.; John Wiley \& Sons: Hoboken, NJ, USA, 2015; pp. 267-306.

26. Pournajaf, A.; Rajabnia, R.; Sedighi, M.; Kassani, A.; Moqarabzadeh, V.; Lotfollahi, L.; Ardebilli, A.; Emadi, B.; Irajian, G. Prevalence, and virulence determination of Listeria monocytogenes strains isolated from clinical and non-clinical samples by multiplex polymerase chain reaction. Rev. Soc. Bras. Med. Trop. 2016, 49, 624-627. [CrossRef]

27. Nguyen, B.N.; Peterson, B.N.; Portnoy, D.A. Listeriolysin O: A phagosome-specific cytolysin revisited. Cell Microbiol. 2019, 21, e12988. [CrossRef] [PubMed]

28. Egan, K.; Field, D.; Rea, M.C.; Ross, R.P.; Hill, C.; Cotter, P.D. Bacteriocins: Novel Solutions to Age Old Spore-Related Problems? Front. Microbiol. 2016, 7, 461. [CrossRef] [PubMed]

29. Kasra-Kermanshahi, R.; Mobarak-Qamsari, E. Inhibition Effect of Lactic Acid Bacteria against Food Born Pathogen, Listeria monocytogenes. Appl. Food Biotechnol. 2015, 2, 11-19.

30. Kumariya, R.; Garsa, A.K.; Rajput, Y.S.; Sood, S.K.; Akhtar, N.; Patel, S. Bacteriocins: Classification, synthesis, mechanism of action and resistance development in food spoilage causing bacteria. Microb. Pathog. 2019, 128, 171-177. [CrossRef]

31. Vijayakumar, P.P.; Muriana, P.M. Inhibition of Listeria monocytogenes on Ready-to-Eat Meats Using Bacteriocin Mixtures Based on Mode-of-Action. Foods 2017, 6, 22. [CrossRef] [PubMed]

32. Zdolec, N.; Hadziosmanovic, M.; Kozacinski, L.; Cvrtila, Z.; Filipovic, I. Influence of protective cultures on Listeria monocytogenes in fermented sausages: A review. Arch. Lebensmittelhyg. 2008, 59, 60-64. [CrossRef]

33. Scatassa, M.L.; Gaglio, R.; Cardamone, C.; Macaluso, G.; Arcuri, L.; Todaro, M.; Mancuso, I. Anti-Listeria activity of lactic acid bacteria in two traditional Sicilian cheeses. Ital. J. Food Saf. 2017, 6, 13-17. [CrossRef]

34. Singh, V.P. Recent approaches in food bio-preservation a review. Open Vet. J. 2018, 8, 104-111. [CrossRef]

35. Amin, R.A. Effect of Bio Preservation as a Modern Technology on Quality Aspects and Microbial Safety on Minced Beef. GJBB 2012, 7, 38-49. 
36. Lu, S.; Xia, Q. Effects of Combined Treatments with Modified-Atmosphere Packaging on Shelf-Life Improvement of Food Products. In Progress in Food Preservation; Bhat, R., Alias, A.K., Paliyath, G., Eds.; John Wiley \& Sons: Hoboken, NJ, USA, 2012; pp. 67-110.

37. Brito, M.A.; Somkuti, G.A.; Renye, J.A., Jr. Production of antilisterial bacteriocins by Staphylococci isolated from bovine milk. J. Dairy Sci. 2011, 94, 1194-1200. [CrossRef]

38. Burkholder, K.M.; Fletcher, D.H.; Gileau, L.; Kandolo, A. Lactic acid bacteria decrease Salmonella enterica Javiana virulence and modulate host inflammation during infection of an intestinal epithelial cell line. Pathog. Dis. 2019, 77. [CrossRef] [PubMed]

39. Vieco-Saiz, N.; Belguesmia, Y.; Raspoet, R.; Auclair, E.; Gancel, F.; Kempf, I.; Drider, D. Benefits and Inputs From Lactic Acid Bacteria and Their Bacteriocins as Alternatives to Antibiotic Growth Promoters During Food-Animal Production. Front. Microbiol. 2019, 10. [CrossRef]

40. Castellano, P.; Ibarreche, M.; Massani, M.; Fontana, C.; Vignolo, G. Strategies for Pathogen Biocontrol Using Lactic Acid Bacteria and Their Metabolites: A Focus on Meat Ecosystems and Industrial Environments. Microorganisms 2017, 5, 38. [CrossRef] [PubMed]

41. Corr, S.C.; Hill, C.; Gahan, C.G.M. Understanding the Mechanisms by Which Probiotics Inhibit Gastrointestinal Pathogens. In Advances in Food and Nutrition Research; Taylor, S., Ed.; Academic Press: Cambridge, MA, USA, 2011; Volume 56, pp. 1-15.

42. Slozilova, I.; Purkrtova, S.; Kosova, M.; Mihulova, M.; Svirakova, E.; Demnerova, K. Antilisterial Activity of Lactic Acid Bacteria against Listeria monocytogenes Strains Originating from Different Sources. Czech J. Food Sci. 2014, 32, 145-151. [CrossRef]

43. Becattini, S.; Pamer, E.G. Multifaceted Defense against Listeria monocytogenes in the Gastro-Intestinal Lumen. Pathogens 2018, 7, 1. [CrossRef]

44. Sun, Y.; O’Riordan, M.X.D. Regulation of Bacterial Pathogenesis by Intestinal Short-Chain Fatty Acids. Adv. Appl. Microbiol. 2013, 85, 93-118. [CrossRef]

45. Rios-Covian, D.; Nogacka, A.; Salazar, N.; Hernandez-Barranco, A.M.; Cuesta, I.; Gueimonde, M.; de Los Reyes Gavilan, C.G. Bifidobacterium breve IPLA20005 affects in vitro the expression of hly and luxS genes, related to the virulence of Listeria monocytogenes Lm23. Can. J. Microbiol. 2018, 64, 215-221. [CrossRef] [PubMed]

46. Wemmenhove, E.; van Valenberg, H.J.F.; van Hooijdonk, A.C.M.; Wells-Bennik, M.H.J.; Zwietering, M.H. Factors that inhibit growth of Listeria monocytogenes in nature-ripened Gouda cheese: A major role for undissociated lactic acid. Food Control 2018, 84, 413-418. [CrossRef]

47. Heir, E.; Liland, K.H.; Carlehog, M.; Hoick, A.L. Reduction and inhibition of Listeria monocytogenes in cold-smoked salmon by Verdad N6, a buffered vinegar fermentate, and UV-C treatments. Int. J. Food Microbiol. 2019, 291, 48-58. [CrossRef]

48. Gonzalez-Fandos, E.; Herrera, B.; Maya, N.; Garcia-Fernandez, C. Efficacy of acetic acid against Listeria monocytogenes attached to poultry skin during refrigerated storage. Foods 2014, 3, 527. [CrossRef]

49. Bermudez-Brito, M.; Plaza-Diaz, J.; Munoz-Quezada, S.; Gomez-Llorente, C.; Gil, A. Probiotic mechanisms of action. Ann. Nutr. Metab. 2012, 61, 160-174. [CrossRef]

50. Fontana, C.; Cocconcelli, P.S.; Vignolo, G.; Saavedra, L. Occurrence of antilisterial structural bacteriocins genes in meat borne lactic acid bacteria. Food Control 2015, 47, 53-59. [CrossRef]

51. Silva, C.C.G.; Silva, S.P.M.; Ribeiro, S.C. Application of Bacteriocins and Protective Cultures in Dairy Food Preservation. Front. Microbiol. 2018, 9. [CrossRef]

52. Abbasiliasi, S.; Tan, J.S.; Ibrahim, T.A.T.; Bashokouh, F.; Ramakrishnan, N.R.; Mustafa, S.; Ariff, A.B. Fermentation factors influencing the production of bacteriocins by lactic acid bacteria: A review. RSC Adv. 2017, 7, 29395-29420. [CrossRef]

53. Ibrahim, O.O. Classification of Antimicrobial Peptides Bacteriocins, and the Nature of Some Bacteriocins with Potential Applications in Food Safety and Bio-Pharmaceuticals. ECMI 2019, 15, 591-608.

54. Jeong, Y.J.; Moon, G.S. Antilisterial Bacteriocin from Lactobacillus rhamnosus CJNU 0519 Presenting a Narrow Antimicrobial Spectrum. Korean J. Food Sci. Anim. Resour. 2015, 35, 137-142. [CrossRef]

55. Trinetta, V.; Morleo, A.; Sessa, F.; Iametti, S.; Bonomi, F.; Ferranti, P. Purified sakacin A shows a dual mechanism of action against Listeria spp: Proton motive force dissipation and cell wall breakdown. FEMS Microbiol. Lett. 2012, 334, 143-149. [CrossRef]

56. Le Blay, G.; Hammami, R.; Lacroix, C.; Fliss, I. Stability and Inhibitory Activity of Pediocin PA-1 Against Listeria sp. in Simulated Physiological Conditions of the Human Terminal Ileum. Probiotics Antimicrob. 2012, 4, 250-258. [CrossRef] [PubMed]

57. Ghrairi, T.; Chaftar, N.; Hani, K. Bacteriocins: Recent Advances and Opportunities. In Progress in Food Preservation; Bhat, R., Alias, A.K., Paliyath, G., Eds.; John Wiley \& Sons: Hoboken, NJ, USA, 2012; pp. 513-530.

58. Gao, Z.H.; Daliri, E.B.M.; Wang, J.; Liu, D.H.; Chen, S.G.; Ye, X.Q.; Ding, T. Inhibitory Effect of Lactic Acid Bacteria on Foodborne Pathogens: A Review. J. Food Protect. 2019, 82, 441-453. [CrossRef] [PubMed]

59. Renye, J.A.; Somkuti, G.; Paul, M.; Van Hekken, D. Characterization of antilisterial bacteriocins produced by Enterococcus faecium and Enterococcus durans isolates from Hispanic-style cheeses. J. Ind. Microbiol. Biotechnol. 2009, 36, 261-268. [CrossRef] [PubMed]

60. Amezquita, A.; Brashears, M.M. Competitive inhibition of Listeria monocytogenes in ready-to-eat meat products by lactic acid bacteria. J. Food Protect. 2002, 65, 316-325. [CrossRef] [PubMed]

61. Kjos, M.; Nes, I.F.; Diep, D.B. Mechanisms of Resistance to Bacteriocins Targeting the Mannose Phosphotransferase System. Appl. Environ. Microb. 2011, 77, 3335-3342. [CrossRef] [PubMed]

62. Yang, E.; Fan, L.; Yan, J.; Jiang, Y.; Doucette, C.; Fillmore, S.; Walker, B. Infuence of culture media, pH and temperature on growth and bacteriocin production of bacteriocinogenic lactic acid bacteria. AMB Express 2018, 8. [CrossRef] 
63. Md Sidek, N.L.; Halim, M.; Tan, J.S.; Abbasiliasi, S.; Mustafa, S.; Ariff, A.B. Stability of Bacteriocin-Like Inhibitory Substance (BLIS) Produced by Pediococcus acidilactici kp10 at Different Extreme Conditions. BioMed Res. Int. 2018, 2018, 5973484. [CrossRef] [PubMed]

64. Drider, D.; Fimland, G.; Hechard, Y.; McMullen, L.M.; Prevost, H. The continuing story of class IIa bacteriocins. Microbiol. Mol. Biol. Rev. 2006, 70, 564. [CrossRef] [PubMed]

65. Ennahar, S.; Sashihara, T.; Sonomoto, K.; Ishizaki, A. Class IIa bacteriocins: Biosynthesis, structure and activity. FEMS Microbiol. Rev. 2000, 24, 85-106. [CrossRef]

66. Chang, C.; Coggill, P.; Bateman, A.; Finn, R.D.; Cymborowski, M.; Otwinowski, Z.; Minor, W.; Volkart, L.; Joachimiak, A. The structure of pyogenecin immunity protein, a novel bacteriocin-like immunity protein from Streptococcus pyogenes. BMC Struct. Biol. 2009, 9, 75. [CrossRef] [PubMed]

67. Perez, R.H.; Zendo, T.; Sonomoto, K. Novel bacteriocins from lactic acid bacteria (LAB): Various structures and applications. Microb. Cell Fact. 2014, 13 (Suppl 1), S3. [CrossRef]

68. Saraoui, T.; Fall, P.A.; Leroi, F.; Antignac, J.P.; Chereau, S.; Pilet, M.F. Inhibition mechanism of Listeria monocytogenes by a bioprotective bacteria Lactococcus piscium CNCM I-4031. Food Microbiol. 2016, 53, 70-78. [CrossRef] [PubMed]

69. Ndahetuye, J.B.; Koo, O.K.; O’Bryan, C.A.; Ricke, S.C.; Crandall, P.G. Role of Lactic Acid Bacteria as a Biosanitizer To Prevent Attachment of Listeria monocytogenes F6900 on Deli Slicer Contact Surfaces. J. Food Protect. 2012, 75, 1429-1436. [CrossRef]

70. Wang, L.; He, Z.; Tian, P.; Wang, G. Lactic Acid Bacteria and Host Immunity. In Lactic Acid Bacteria: Omics and Functional Evaluation; Chen, W., Ed.; Springer: New York, NY, USA, 2019; pp. 261-296.

71. Garriga, M.; Rubio, R.; Aymerich, T.; Ruas-Madiedo, P. Potentially probiotic and bioprotective lactic acid bacteria starter cultures antagonise the Listeria monocytogenes adhesion to HT29 colonocyte-like cells. Benef. Microbes 2015, 6, 337-343. [CrossRef]

72. Zilelidou, E.A.; Rychli, K.; Manthou, E.; Ciolacu, L.; Wagner, M.; Skandamis, P.N. Highly Invasive Listeria monocytogenes Strains Have Growth and Invasion Advantages in Strain Competition. PLoS ONE 2015, 10, e0141617. [CrossRef]

73. Hu, Y.; Raengpradub, S.; Schwab, U.; Loss, C.; Orsi, R.H.; Wiedmann, M.; Boor, K.J. Phenotypic and Transcriptomic Analyses Demonstrate Interactions between the Transcriptional Regulators CtsR and Sigma B in Listeria monocytogenes. Appl. Environ. Microb. 2007, 73, 7967-7980. [CrossRef] [PubMed]

74. Herich, R.; Levkut, M. Lactic acid bacteria, probiotics and immune system. Vet. Med.-Czech 2002, 47, 169-180. [CrossRef]

75. Ortega, F.E.; Rengarajan, M.; Chavez, N.; Radhakrishnan, P.; Gloerich, M.; Bianchini, J.; Siemers, K.; Luckett, W.S.; Lauer, P.; Nelson, W.J.; et al. Adhesion to the host cell surface is sufficient to mediate Listeria monocytogenes entry into epithelial cells. Mol. Biol. Cell 2017, 28, 2945-2957. [CrossRef] [PubMed]

76. Popovic, N.; Djokic, J.; Brdaric, E.; Dinic, M.; Terzic-Vidojevic, A.; Golic, N.; Veljovic, K. The Influence of Heat-Killed Enterococcus faecium BGPAS1-3 on the Tight Junction Protein Expression and Immune Function in Differentiated Caco-2 Cells Infected With Listeria monocytogenes ATCC 19111. Front. Microbiol. 2019, 10, 412. [CrossRef] [PubMed]

77. Corr, S.C.; Gahan, C.G.; Hill, C. Impact of selected Lactobacillus and Bifidobacterium species on Listeria monocytogenes infection and the mucosal immune response. FEMS Immunol. Med. Microbiol. 2007, 50, 380-388. [CrossRef] [PubMed]

78. Nishiyama, K.; Sugiyama, M.; Mukai, T. Adhesion Properties of Lactic Acid Bacteria on Intestinal Mucin. Microorganisms 2016, 4, 34. [CrossRef]

79. Upadhyay, A.; Upadhyaya, I.; Mooyottu, S.; Venkitanarayanan, K. Eugenol in combination with lactic acid bacteria attenuates Listeria monocytogenes virulence in vitro and in invertebrate model Galleria mellonella. J. Med. Microbiol. 2016, 65, 443-455. [CrossRef]

80. Winkelstroter, L.K.; De Martinis, E.C. Effect of Bacteriocins and Conditions that Mimic Food and Digestive Tract on Biofilm Formation, In Vitro Invasion of Eukaryotic Cells and Internalin Gene Expression by Listeria monocytogenes. Probiotics Antimicrob. Proteins 2013, 5, 153-164. [CrossRef]

81. Yun, B.; Oh, S.; Griffiths, M.W. Lactobacillus acidophilus modulates the virulence of Clostridium difficile. J. Dairy Sci. 2014, 97, 4745-4758. [CrossRef]

82. Allaart, J.G.; van Asten, A.J.A.M.; Vernooij, J.C.M.; Grone, A. Effect of Lactobacillus fermentum on Beta2 Toxin Production by Clostridium perfringens. Appl. Environ. Microb. 2011, 77, 4406-4411. [CrossRef]

83. Regan, T.; Nally, K.; Carmody, R.; Houston, A.; Shanahan, F.; MacSharry, J.; Brint, E. Identification of TLR10 as a Key Mediator of the Inflammatory Response to Listeria monocytogenes in Intestinal Epithelial Cells and Macrophages. J. Immunol. 2013, 191, 6084-6092. [CrossRef]

84. Galdeano, C.M.; Cazorla, S.I.; Dumit, J.M.L.; Velez, E.; Perdigon, G. Beneficial Effects of Probiotic Consumption on the Immune System. Ann. Nutr. Metab. 2019, 74, 115-124. [CrossRef]

85. Schuppler, M.; Loessner, M.J. The Opportunistic Pathogen Listeria monocytogenes: Pathogenicity and Interaction with the Mucosal Immune System. Int. J. Inflam. 2010, 2010, 704321. [CrossRef] [PubMed]

86. Zenewicz, L.A.; Shen, H. Innate and adaptive immune responses to Listeria monocytogenes: A short overview. Microbes Infect. 2007, 9, 1208-1215. [CrossRef] [PubMed]

87. Aliakbarpour, H.R.; Chamani, M.; Rahimi, G.; Sadeghi, A.A.; Qujeq, D. The Bacillus subtilis and Lactic Acid Bacteria Probiotics Influences Intestinal Mucin Gene Expression, Histomorphology and Growth Performance in Broilers. Asian Austral. J. Anim. 2012, 25, 1285-1293. [CrossRef] [PubMed]

88. Ren, C.; Dokter-Fokkens, J.; Lozano, S.F.; Zhang, Q.; de Haan, B.J.; Zhang, H.; Faas, M.M.; de Vos, P. Lactic Acid Bacteria May Impact Intestinal Barrier Function by Modulating Goblet Cells. Mol. Nutr. Food Res. 2018, 62, 1-14. [CrossRef] 
89. Habil, N.; Abate, W.; Beal, J.; Foey, A.D. Heat-killed probiotic bacteria differentially regulate colonic epithelial cell production of human beta-defensin-2: Dependence on inflammatory cytokines. Benef. Microbes 2014, 5, 483-495. [CrossRef]

90. Ferrand, A.; Al Nabhani, Z.; Tapias, N.S.; Mas, E.; Hugot, J.P.; Barreau, F. NOD2 Expression in Intestinal Epithelial Cells Protects Toward the Development of Inflammation and Associated Carcinogenesis. Cell Mol. Gastroenterol. Hepatol. $2019,7,357-369$. [CrossRef] [PubMed]

91. Caballero-Franco, C.; Keller, K.; De Simone, C.; Chadee, K. The VSL\#3 probiotic formula induces mucin gene expression and secretion in colonic epithelial cells. Am. J. Physiol. Gastrointest. Liver Physiol. 2007, 292, G315-G322. [CrossRef]

92. Fernandez, N.; Wrzosek, L.; Radziwill-Bienkowska, J.M.; Ringot-Destrez, B.; Duviau, M.P.; Noordine, M.L.; Laroute, V.; Robert, V.; Cherbuy, C.; Daveran-Mingot, M.L.; et al. Characterization of Mucus-Related Properties of Streptococcus thermophilus: From Adhesion to Induction. Front. Physiol. 2018, 9, 980. [CrossRef] [PubMed]

93. Galina, D.; Ansonska, L.; Valdovska, A. Effect of Probiotics and Herbal Products on Intestinal Histomorphological and Immunological Development in Piglets. Vet. Med. Int. 2020, 2020, 3461768. [CrossRef] [PubMed]

94. Wang, L.; Cao, H.; Liu, L.; Wang, B.; Walker, W.A.; Acra, S.A.; Yan, F. Activation of epidermal growth factor receptor mediates mucin production stimulated by p40, a Lactobacillus rhamnosus GG-derived protein. J. Biol. Chem. 2014, 289, 20234-20244. [CrossRef] [PubMed]

95. van Beek, A.A.; Sovran, B.; Hugenholtz, F.; Meijer, B.; Hoogerland, J.A.; Mihailova, V.; van der Ploeg, C.; Belzer, C.; Boekschoten, M.V.; Hoeijmakers, J.H.J.; et al. Supplementation with Lactobacillus plantarum WCFS1 Prevents Decline of Mucus Barrier in Colon of Acclerated Aging Ercc1(-/Delta 7) Mice. Front. Immunol. 2016, 7. [CrossRef] [PubMed]

96. Frøkiær, H. Probiotics and the Immune System. In Lactic Acid Bacteria: Microbiological and Functional Aspects, 5th ed.; Vinderola, G., Ouwehand, A.C., Salminen, S., von Wright, A., Eds.; CRC Press: Boca Raton, FL, USA, 2019; pp. 423-440.

97. Wang, H.; Kim, J.J.; Denou, E.; Gallagher, A.; Thornton, D.J.; Shajib, M.S.; Xia, L.; Schertzer, J.D.; Grencis, R.K.; Philpott, D.J.; et al. New Role of Nod Proteins in Regulation of Intestinal Goblet Cell Response in the Context of Innate Host Defense in an Enteric Parasite Infection. Infect. Immun. 2016, 84, 275-285. [CrossRef]

98. Bierne, H.; Cossart, P. Listeria monocytogenes surface proteins: From genome predictions to function. Microbiol. Mol. Biol. Rev. 2007, 71,377-397. [CrossRef]

99. Rinehart, E.; Chapman, J.; Sun, Y. The Production of Listeriolysin O and Subsequent Intracellular Infections by Listeria monocytogenes Are Regulated by Exogenous Short Chain Fatty Acid Mixtures. Toxins 2020, 12, 218. [CrossRef]

100. Pentecost, M.; Otto, G.; Theriot, J.A.; Amieva, M.R. Listeria monocytogenes invades the epithelial junctions at sites of cell extrusion. PLoS Pathog. 2006, 2, 29-40. [CrossRef]

101. Drolia, R.; Tenguria, S.; Durkes, A.C.; Turner, J.R.; Bhunia, A.K. Listeria Adhesion Protein Induces Intestinal Epithelial Barrier Dysfunction for Bacterial Translocation. Cell Host. Microbe 2018, 23, 470-484. [CrossRef]

102. Kim, H.; Bhunia, A.K. Secreted Listeria adhesion protein (Lap) influences Lap-mediated Listeria monocytogenes paracellular translocation through epithelial barrier. Gut Pathog. 2013, 5. [CrossRef]

103. Koo, O.K.; Amalaradjou, M.A.; Bhunia, A.K. Recombinant probiotic expressing Listeria adhesion protein attenuates Listeria monocytogenes virulence in vitro. PLoS ONE 2012, 7, e29277. [CrossRef]

104. Burkholder, K.M.; Bhunia, A.K. Listeria monocytogenes uses Listeria adhesion protein (LAP) to promote bacterial transepithelial translocation and induces expression of LAP receptor Hsp60. Infect. Immun. 2010, 78, 5062-5073. [CrossRef]

105. Mathipa, M.G.; Bhunia, A.K.; Thantsha, M.S. Internalin AB-expressing recombinant Lactobacillus casei protects Caco-2 cells from Listeria monocytogenes-induced damages under simulated intestinal conditions. PLoS ONE 2019, 14, e0220321. [CrossRef]

106. Corr, S.C.; O'Neill, L.A.J. Listeria monocytogenes infection in the face of innate immunity. Cell. Microbiol. 2009, 11, 703-709. [CrossRef] [PubMed]

107. Pamer, E.G. Immune responses to Listeria monocytogenes. Nat. Rev. Immunol. 2004, 4, 812-823. [CrossRef] [PubMed]

108. D'Orazio, S.E.F. Innate and Adaptive Immune Responses during Listeria monocytogenes Infection. Microbiol. Spectr. 2019, 7. [CrossRef]

109. Dussurget, O.; Bierne, H.; Cossart, P. The bacterial pathogen Listeria monocytogenes and the interferon family: Type I, type II and type III interferons. Front. Cell Infect. Microbiol. 2014, 4, 50. [CrossRef] [PubMed]

110. Llewellyn, A.; Foey, A. Probiotic Modulation of Innate Cell Pathogen Sensing and Signaling Events. Nutrients 2017, 9, 1156. [CrossRef]

111. Elbanna, K.; El Hadad, S.; Assaeedi, A.; Aldahlawi, A.; Khider, M.; Alhebshi, A. In vitro and in vivo evidences for innate immune stimulators lactic acid bacterial starters isolated from fermented camel dairy products. Sci. Rep. 2018, 8, 12553. [CrossRef]

112. Ouellette, A.J.; Selsted, M.E. Paneth Cell $\alpha$-Defensins. In Handbook of Biologically Active Peptides, 2nd ed.; Kastin, A.J., Ed.; Academic Press: Cambridge, MA, USA, 2013; pp. 1300-1306.

113. Arnett, E.; Lehrer, R.I.; Pratikhya, P.; Lu, W.Y.; Seveau, S. Defensins enable macrophages to inhibit the intracellular proliferation of Listeria monocytogenes. Cell. Microbiol. 2011, 13, 635-651. [CrossRef] [PubMed]

114. Menard, S.; Forster, V.; Lotz, M.; Gutle, D.; Duerr, C.U.; Gallo, R.L.; Henriques-Normark, B.; Putsep, K.; Andersson, M.; Glocker, E.O.; et al. Developmental switch of intestinal antimicrobial peptide expression. J. Exp. Med. 2008, 205, 183-193. [CrossRef] [PubMed]

115. Okumura, R.; Takeda, K. Roles of intestinal epithelial cells in the maintenance of gut homeostasis. Exp. Mol. Med. 2017, 49. [CrossRef] [PubMed]

116. Andersson, M.L.; Karlsson-Sjoberg, J.M.; Putsep, K.L. CRS-peptides: Unique defense peptides of mouse Paneth cells. Mucosal. Immunol. 2012, 5, 367-376. [CrossRef] [PubMed] 
117. Shanahan, M.T.; Carroll, I.M.; Gulati, A.S. Critical design aspects involved in the study of Paneth cells and the intestinal microbiota. Gut Microbes 2014, 5, 208-214. [CrossRef]

118. Wells, J.M. Immunomodulatory mechanisms of Lactobacilli. Microb. Cell Fact. 2011, 10 (Suppl 1), S17. [CrossRef]

119. Kobatake, E.; Kabuki, T. S-Layer Protein of Lactobacillus helveticus SBT2171 Promotes Human beta-Defensin 2 Expression via TLR2-JNK Signaling. Front. Microbiol. 2019, 10, 2414. [CrossRef] [PubMed]

120. Lochner, M.; Kastenmuller, K.; Neuenhahn, M.; Weighardt, H.; Busch, D.H.; Reindl, W.; Forster, I. Decreased Susceptibility of Mice to Infection with Listeria monocytogenes in the Absence of Interleukin-18. Infect. Immun. 2008, 76, 3881-3890. [CrossRef]

121. Carrero, J.A.; Unanue, E.R. Mechanisms and Immunological Effects of Apoptosis Caused by Listeria monocytogenes. In Advances in Immunology; Unanue, E.R., Carrero, J.A., Eds.; Academic Press: Cambridge, MA, USA, 2012; Volume 113, pp. 157-174.

122. McDougal, C.E.; Sauer, J.D. Listeria monocytogenes: The Impact of Cell Death on Infection and Immunity. Pathogens $2018,7,8$. [CrossRef]

123. Yan, F.; Cao, H.W.; Cover, T.L.; Whitehead, R.; Washington, M.K.; Polk, D.B. Soluble proteins produced by probiotic bacteria regulate intestinal epithelial cell survival and growth. Gastroenterology 2007, 132, 562-575. [CrossRef]

124. Yan, F.; Cao, H.; Cover, T.L.; Kay Washington, M.; Shi, Y.; Liu, L.; Chaturvedi, R.; Peek, R.M.; Wilson, K.T.; Brent Polk, D. Colonspecific delivery of a probiotic-derived soluble protein ameliorates intestinal inflammation in mice through an EGFR-dependent mechanism. J. Clin. Invest. 2011, 121, 2242-2253. [CrossRef] [PubMed]

125. Tsai, Y.T.; Cheng, P.C.; Pan, T.M. The immunomodulatory effects of lactic acid bacteria for improving immune functions and benefits. Appl. Microbiol. Biotechnol. 2012, 96, 853-862. [CrossRef] [PubMed]

126. Yang, L.; Higginbotham, J.N.; Liu, L.; Zhao, G.; Acra, S.A.; Peek, R.M.; Brent Polk, D.; Li, H.; Yan, F. Production of a Functional Factor, p40, by Lactobacillus rhamnosus GG Is Promoted by Intestinal Epithelial Cell Secreted Extracellular Vesicles. Infect. Immun. 2019, 87, 1-17. [CrossRef]

127. Ren, C.; Zhang, Q.; de Haan, B.J.; Zhang, H.; Faas, M.M.; de Vos, P. Identification of TLR2/TLR6 signalling lactic acid bacteria for supporting immune regulation. Sci. Rep. 2016, 6, 34561. [CrossRef] [PubMed]

128. Ren, C.; Cheng, L.; Sun, Y.; Zhang, Q.; de Haan, B.J.; Zhang, H.; Faas, M.M.; de Vos, P. Lactic acid bacteria secrete toll like receptor 2 stimulating and macrophage immunomodulating bioactive factors. J. Funct. Foods 2020, 66, 103783. [CrossRef]

129. Stavru, F.; Archambaud, C.; Cossart, P. Cell biology and immunology of Listeria monocytogenes infections: Novel insights. Immunol. Rev. 2011, 240, 160-184. [CrossRef]

130. Williams, M.A.; Schmidt, R.L.; Lenz, L.L. Early events regulating immunity and pathogenesis during Listeria monocytogenes infection. Trends Immunol. 2012, 33, 488-495. [CrossRef] [PubMed]

131. Vilander, A.C.; Dean, G.A. Adjuvant Strategies for Lactic Acid Bacterial Mucosal Vaccines. Vaccines 2019, 7, 150. [CrossRef]

132. Koster, S.; van Pee, K.; Hudel, M.; Leustik, M.; Rhinow, D.; Kuhlbrandt, W.; Chakraborty, T.; Yildiz, O. Crystal structure of listeriolysin $\mathrm{O}$ reveals molecular details of oligomerization and pore formation. Nat. Commun. 2014, 5, 3690. [CrossRef]

133. Hernandez-Flores, K.G.; Vivanco-Cid, H. Biological effects of listeriolysin O: Implications for vaccination. BioMed Res. Int. 2015, 2015, 360741. [CrossRef]

134. Szatraj, K.; Szczepankowska, A.K.; Chmielewska-Jeznach, M. Lactic acid bacteria promising vaccine vectors: Possibilities, limitations, doubts. J. Appl. Microbiol. 2017, 123, 325-339. [CrossRef]

135. Mercenier, A.; Muller-Alouf, H.; Grangette, C. Lactic acid bacteria as live vaccines. Curr. Issues Mol. Biol. 2000, 2, 17-25. [CrossRef]

136. Wyszynska, A.; Kobierecka, P.; Bardowski, J.; Jagusztyn-Krynicka, E.K. Lactic acid bacteria-20 years exploring their potential as live vectors for mucosal vaccination. Appl. Microbiol. Biotechnol. 2015, 99, 2967-2977. [CrossRef] [PubMed]

137. Azizpour, M.; Hosseini, S.D.; Jafari, P.; Akbary, N. Lactococcus lactis: A New Strategy for Vaccination. Avicenna J. Med. Biotechnol. 2017, 9, 163-168.

138. De Azevedo, M.S.; Santos Rocha, C.; Pereira, V.B.; De Oliveira Junior, A.F.; De Sousa, C.S.; Azevedo, V.; LeBlanc, J.G.; Chatel, J.M.; Miyoshi, A. Prospective uses of recombinant Lactococcus lactis expressing both listeriolysin $\mathrm{O}$ and mutated internalin A from Listeria monocytogenes as a tool for DNA vaccination. Genet. Mol. Res. 2015, 14, 18485-18493. [CrossRef]

139. Chamberlain, L.; Wells, J.M.; Robinson, K.; Schofield, K.; Le Page, R.W.F. Mucosal Immunization With Recombinant Lactococcus lactis. In Gram-Positive Bacteria as Vaccine Vehicles for Mucosal Immunization; Pozzi, G., Wells, J.M., Eds.; Landes Bioscience: Austin, TX, USA, 1997; pp. 83-106.

140. Jensen, S.; Steffensen, M.A.; Jensen, B.A.; Schluter, D.; Christensen, J.P.; Thomsen, A.R. Adenovirus-based vaccine against Listeria monocytogenes: Extending the concept of invariant chain linkage. J. Immunol. 2013, 191, 4152-4164. [CrossRef] [PubMed]

141. Marcotte, H.; Koll-Klais, P.; Hultberg, A.; Zhao, Y.; Gmur, R.; Mandar, R.; Mikelsaar, M.; Hammarstrom, L. Expression of single-chain antibody against RgpA protease of Porphyromonas gingivalis in Lactobacillus. J. Appl. Microbiol. 2006, 100, 256-263. [CrossRef] [PubMed]

142. Abrami, L.; Reig, N.; van der Goot, F.G. Anthrax toxin: The long and winding road that leads to the kill. Trends Microbiol. 2005, 13, 72-78. [CrossRef] [PubMed]

143. Davidson, P.M.; Critzer, F.M. Interventions to Inhibit or Inactivate Bacterial Pathogens in Foods. In Microbial Food Safety: An Introduction; Oyarzabal, O.A., Backert, S., Eds.; Springer Science \& Business Media: New York, NY, USA, 2012 ; pp. 189-202.

144. Kong, F.; Singh, R.P. Chemical Deterioration and Physical Instability of Foods and Beverages. In The Stability and Shelf Life of Food, 2nd ed.; Subramaniam, P., Wareing, P., Eds.; Woodhead Publishing: Cambridge, UK, 2016.

145. Mahmud, A.; Abraha, B.; Samuel, M.; Mohammedidris, H.; Abraham, W.; Mahmud, E. Fish preservation: A multi-dimensional approach. MOJ Food Process Technol. 2018, 6, 303-310. [CrossRef] 
146. Zacharof, M.P.; Lovitt, R.W. Bacteriocins Produced by Lactic Acid Bacteria A Review Article. APCBEE Procedia 2012,2 , 50-56. [CrossRef]

147. Abdollahzadeh, E.; Rezaei, M.; Hosseini, H. Antibacterial activity of plant essential oils and extracts: The role of thyme essential oil, nisin, and their combination to control Listeria monocytogenes inoculated in minced fish meat. Food Control 2014, 35, 177-183. [CrossRef]

148. Martinez, R.C.R.; Alvarenga, V.O.; Thomazini, M.; Favaro-Trindade, C.S.; Sant'Ana, A.D. Assessment of the inhibitory effect of free and encapsulated commercial nisin (Nisaplin (R)), tested alone and in combination, on Listeria monocytogenes and Bacillus cereus in refrigerated milk. LWT-Food Sci. Technol. 2016, 68, 67-75. [CrossRef]

149. Kouakou, P.; Kahenouin, G.O.; Biego, G.H.M. Controlling Listeria monocytogenes on Pork Meat with Combinations of Lyophilized Cell-adsorbed Bacteriocin of Lactobacillus curvatus CWBI-B28 and Organic Acids or Salts. J. Microbiol. Biotechnol. 2016, 5, $22-26$.

150. Linares-Morales, J.R.; Gutierrez-Mendez, N.; Rivera-Chavira, B.E.; Perez-Vega, S.B.; Nevarez-Moorillon, G.V. Biocontrol Processes in Fruits and Fresh Produce, the Use of Lactic Acid Bacteria as a Sustainable Option. Front. Sustain. Food Syst. 2018, 2. [CrossRef]

151. Cahill, S.M.; Upton, M.E.; Mcloughlin, A.J. Bioencapsulation Technology In Meat Preservation. In Applied Microbiology; Durieux, A., Simon, J.P., Eds.; Springer Science \& Business Media: New York, NY, USA, 2006; Volume 2, pp. $239-266$.

152. Le, N.T.T.; Bach, L.G.; Nguyen, D.C.; Le, T.H.X.; Pham, K.H.; Nguyen, D.H.; Thi, T.T.H. Evaluation of Factors Affecting Antimicrobial Activity of Bacteriocin from Lactobacillus plantarum Microencapsulated in Alginate-Gelatin Capsules and Its Application on Pork Meat as a Bio-Preservative. Int. J. Environ. Res. Public Heath 2019, 16, 1017. [CrossRef] [PubMed]

153. Pinilla, C.M.B.; Brandelli, A. Antimicrobial activity of nanoliposomes co-encapsulating nisin and garlic extract against Grampositive and Gram-negative bacteria in milk. Innov. Food Sci. Emerg. Technol. 2016, 36, 287-293. [CrossRef]

154. Malheiros Pda, S.; Sant'Anna, V.; Barbosa Mde, S.; Brandelli, A.; Franco, B.D. Effect of liposome-encapsulated nisin and bacteriocinlike substance P34 on Listeria monocytogenes growth in Minas frescal cheese. Int. J. Food Microbiol. 2012, 156, 272-277. [CrossRef]

155. da Silva Malheiros, P.; Daroit, D.J.; Brandelli, A. Inhibition of Listeria Monocytogenes in Minas Frescal Cheese by Free and Nanovesicle-encapsulated Nisin. Braz. J. Microbiol. 2012, 1414-1418. [CrossRef]

156. Barbosa, M.S.; Todorov, S.D.; Jurkiewicz, C.H.; Franco, B.D.G.M. Bacteriocin production by Lactobacillus curvatus MBSa2 entrapped in calcium alginate during ripening of salami for control of Listeria monocytogenes. Food Control 2015, 47, 147-153. [CrossRef]

157. Yildirim, S.; Rocker, B.; Pettersen, M.K.; Nilsen-Nygaard, J.; Ayhan, Z.; Rutkaite, R.; Radusin, T.; Suminska, P.; Marcos, B.; Coma, V. Active Packaging Applications for Food. Compr. Rev. Food Sci. Food Saf. 2018, 17, 165-199. [CrossRef]

158. Vignolo, G.; Saavedra, L.; Sesma, F.; Raya, R. Food Bioprotection: Lactic Acid Bacteria as Naural Preservatives. In Progress in Food Preservation; Bhat, R., Alias, A.K., Paliyath, G., Eds.; John Wiley \& Sons: Cambridge, MA, USA, 2012; pp. 451-484.

159. Meister Meira, S.M.; Zehetmeyer, G.; Scheibel, J.M.; Werner, J.O.; Brandelli, A. Starch-halloysite nanocomposites containing nisin: Characterization and inhibition of Listeria monocytogenes in soft cheese. Food Sci. Technol. 2016, 68, 226-234. [CrossRef]

160. Concha-Meyer, A.; Schöbitz, R.; Brito, C.; Fuentes, R. Lactic acid bacteria in an alginate film inhibit Listeria monocytogenes growth on smoked salmon. Food Control 2011, 22, 485-489. [CrossRef]

161. Scannell, A.G.M.; Hill, C.; Ross, R.P.; Marx, S.; Hartmeier, W.; Arendt, E.K. Development of bioactive food packaging materials using immobilised bacteriocins Lacticin 3147 and Nisaplin. Int. J. Food Microbiol. 2000, 60, 241-249. [CrossRef]

162. Pattanayaiying, R.; Kittikun, A.; Cutter, C.N. Incorporation of nisin Z and lauric arginate into pullulan films to inhibit foodborne pathogens associated with fresh and ready-to-eat muscle foods. Int. J. Food Microbiol. 2015, 207, 77-82. [CrossRef] [PubMed]

163. Matamoros, S.; Leroi, F.; Cardinal, M.; Gigout, F.; Kasbi Chadli, F.; Cornet, J.; Prevost, H.; Pilet, M.F. Psychrotrophic Lactic Acid Bacteria Used To Improve the Safety and Quality of Vacuum-Packaged Cooked and Peeled Tropical Shrimp and Cold-Smoked Salmon. J. Food Protect. 2009, 72, 365-374. [CrossRef] 